SAND83-1296

Unlimited Release

UC-70

\title{
BACKGROUND RADIATION MEASUREMENTS AT THE WASTE ISOLATION PILOT PLANT (WIPP) SITE CARLSBAD, NEW MEXICO
}

D. M. Minnema

Division 3312

and

L. W. Brewer

Department 3310

Sandia National Laboratories

Albuquerque, New Mexico 87185

\section{DISCLAIMER}

This report was prepared as an account of work sponsored by an agency of the United States Government. Neither the United States Government nor any agency thereof, nor any of their employees, makes any warranty, express or implied, or assumes any legal liability or responsibility for the accuracy, completeness, or usefulness of any information, apparatus, product, or process disclosed, or represents that its use would not infringe privately owned rights. Reference herein to any specific commercial product, process, or service by trade name, trademark, manufacturer, or otherwise does not necessarily constitute or imply its endorsement, recommendation, or favoring by the United States Government or any agency thereof. The views and opinions of authors expressed herein do not necessarily state or reflect those of the United States Government or any agency thereof.
This document is

PUBLICLY ILLEASABLE Low E gilhame

Authorizing Official

Date: $03 / 10 / 2006$

DISTRIBUTLON OF THIS OOCLIMENT IS UNLIGMTEO 


\section{DISCLAIMER}

This report was prepared as an account of work sponsored by an agency of the United States Government. Neither the United States Government nor any agency Thereof, nor any of their employees, makes any warranty, express or implied, or assumes any legal liability or responsibility for the accuracy, completeness, or usefulness of any information, apparatus, product, or process disclosed, or represents that its use would not infringe privately owned rights. Reference herein to any specific commercial product, process, or service by trade name, trademark, manufacturer, or otherwise does not necessarily constitute or imply its endorsement, recommendation, or favoring by the United States Government or any agency thereof. The views and opinions of authors expressed herein do not necessarily state or reflect those of the United States Government or any agency thereof. 


\section{DISCLAIMER}

Portions of this document may be illegible in electronic image products. Images are produced from the best available original document. 
Eackground Fadiation Measurements at the Waste Isolation Pilot Plant (WIPP) Site, Camlsbad, New Mexico

\section{Abstract}

A serieg of background radiation measurements were performed at the Waste Isolation Filot filant (WIPP) Site, Carlsbad, New Mexico. The survey consisted of gross gamma and gamma spectral measurements of the radiation fields, soil and salt grab sample gamma analysis, and radon and working level measurements. The survey included locations at the surface and also within the mine itself.

background radiation levels on the surface were measured to average 7.65 $\mathrm{microfi} / \mathrm{hour}$, and $0.7 \mathrm{microf} / \mathrm{hour}$ within the mine. Fadon and wort:ing levels were at or below detection levels at all locations, and the radon concentration was estimated to be about $0.01 \mathrm{pCi} / 1 \mathrm{iter}$ on the surface based on spectral measurements. The spectral measurements were performed using an intrinsic germanium spectrometer, and calculations from the spectra indicated that potassium-40 contributed about $28 \%$ to the surface level dose rates, natural uranium daughters contributed about $64 \%$, and cesium-137 from weapons testing fallout contributed about 8\%. In the mine potassium-40 was the only identifiable contributor to the dose rate. 
Background Fadiation Measurements at the Waste Isolation Filot Fiant (WIFP) Site, Carl sbad; New Mexico

\section{INTRODUCTION}

A series of background radiation measurements at the Waste Isolation Pilot Flant (WIPF) Site were made to aid in establishing an introductory baseline for the environmental monitoring program. The background radiation survey involved three discrete measurements that combine to form an overall characterization of the site. The measurements that were performed at the site were:

1. Fadiation Field Spectral Studies: The background radiation field was measured both on the surface and in the mine using a high resolution intrinsic germanium ganna spectrometer. This analysis provides a qualitative and quantitative identification of the contributors to the field.

2. Grab Sample Anelysis: A series of grab samples were taken at: most: of the sites at which the field spectral studies were performed. The samples of soil or salt were analyzed for their radioisotope content and compared with the commesponding madiation field analysis.

3. Airborne Fadionulelide Analysis: A series of air samples were collected at selected sites and analyzed for raclon and radon daughter concentrations in air. "The radon gas was analyzed with standard "Lucas cells" and the daughters were evaluated with standard worbing level (WL.) techriques. These measurements were also compared to the radiation field measurements where appropriate.

This group of measurements provides a basis for establishing the criteria necessary for an effective preoperational monitoring program, and points out areas of concern for" further study"

\section{FADTATION FIELD SFEOTFAL STUDY}

The radiation field opectral study was performed using a high resolution

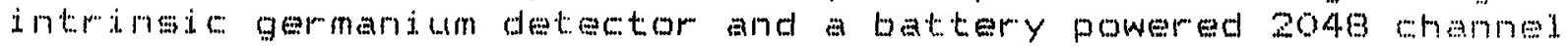

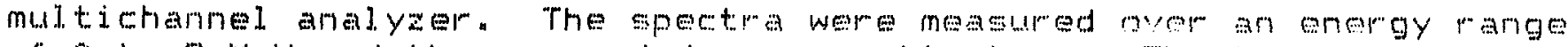
of 0 to 2 Mev and them remored on manetic tape. The tapes were returned to SNLA and transferred to a computer for analysis. Appendix 1 
contains plots of the measured spectra. The spectria were analyzed using a standard peak search routine and the count mates for any identified peaks were determined. Using an appropriate efficjency curve, the peak measurements were converted to yield the comresponcing uncollided photon flux in air". Finally, this uncollided flux was used with suitable models to provide estimates of madionuclide concentrations in the media of concern, and their cormesponding dose rate contributions. As an example of this algomithm, the potassium-40 peak measured in a spectrum is easily converted to an equivalent soil concentration assuming a semi-infinite distribution with the detector near the boundary. The uncoldided $f l u x$ at the boundary is:

where

$$
\left.\left.\phi_{u}=Q_{V} /(2 * 1)=(E)\right) \quad \text { (Eq } 1 \text { ( }\right)
$$

$$
\begin{aligned}
& \phi_{u}=\text { uncollided photon fluk, (photons/en'2-sec): } \\
& Q v=v o l \text { umetric source strength (photons/cma-sec); } \\
& U s(E)=\text { attenuation coefficient for soil for energy } E \text {, (cm). }
\end{aligned}
$$

Defining the source tem as

where

$$
\text { QV }=5 \vee * b * 0.037
$$

$$
\begin{aligned}
S v & =\text { source concentration ( } \mathrm{CCi} / \mathrm{cm} \mathrm{S} \text { ) } \\
b & =\text { branching reatio of photon of interest; and } \\
0.057 & =\text { conversion from } p C i \text { to dps. }
\end{aligned}
$$

The detected uncollided photon flux can be represented by

where

$$
\phi_{u}=R p / e(E) \quad \text { (Eq. } 5 \text { ) }
$$

$$
\begin{aligned}
\text { Fip }= & \text { count rate of peat: in counts per second: } \\
\text { e(E) }= & \text { detector efficiency for energy } E \text { in } \\
& \text { cps/(photons/cm } 2-5 e c) .
\end{aligned}
$$

These equations are combined to yield

$$
\text { SV }=(54,05 * F p * U \mathrm{E}(\mathrm{E})) /(\mathrm{D} * \mathrm{E}(\mathrm{E})) \quad(\mathrm{Eq}, 4) \text {. }
$$

A density of $1.5 \mathrm{gm} / \mathrm{cm} 3$ was used for the conversion to pCi/gm for the soil and $2.17 \mathrm{gm} / \mathrm{cm}$. was used for the salt.

In the K-40 example, the 1461 keV photon has a brariching ratio of 0.11 , an efficiency of 1.65 and an attenuation coefficiert of 0.078 . $A$ count: rate of 0.7 cps yields a concentration of $9.6 \mathrm{pCi} / \mathrm{cm}$ in soil.

This model can also be used for conditions in the mine, only it is convertied to assume an infinite soumce mather than a semi-infinite source. This results in dropping the factor of 2 in equation 1 . The results of these calculations are listed in Table 1 along with the results of the grab samples taken at the same locations. 


\section{GRAE SAMPLE ANALYSIS}

Grab samples were taken at several locations above ground and at two locations in the mine. The samples were placed in standard Marinelli beakers and returned to SNLA for analyisis. Gamma spectroscopy was mun on the samples to determine radioisotopic concentrations for comparison with the radiation field analysis. Analysis is performed using a standard isotope identification program and the calibration is traceable to NES standards. The results of these analyses are listed in Table 1 along with the results of the radiation field measurements for comparison.

After the concentration of radionuclides in the soil has been determined, either through radiation field estimates as described above, or through the use of grab samples as in this section, it is possible to use the results to estimate the radiation exposure levels at ground level using assumptions similar to those in the field analysis section. Reference 1 contains factors for converting from concentrations in soil to dose equivalent pate in aim near ground 1 evel for uniformly distributed sources. From this reference it is found that for fa-226 and daughters in soil the factor is 13.0 (urem/hr)/(uCi/m/3), and for Cs-1.57 (resulting from fallout), the factor is 4.9 (urem/hr) $/\left(u C i / \mathrm{m}^{\circ} \mathrm{g}\right)$. A similar analysis yields a factor for $k-40$ of 0.138 (urem/hr)/(uCi/m 3 ). Calculating dose equivalent rates for each nuclide and summing them allows one to compare these calculated rates to the measured dose rates: and to evaluate fractional contributions from each nuclide. Table 2 contains this evaluation for the grab sample results. compared with pressurized ion chamber (Reuter-stokes) measurements taken at the same time, and with long term averages obtained from sandia"s TLD plants at. selected WIFF sites (reference 4)"

\section{AIREOFINE RADIONUCLIDE ANALYSIS}

A series of air samples were collected at several locations in order to evaluate the airborne contribution to the natural background. It should be noted that while the soil contribution to the background should remain fairly static with time, the airborne contribution is very dependent upon time of day, season, and meteorological conditions at the sampling time. This dependency mainly reflects the conditions affecting the diffusion of radon from the soil into the atmosphere.

Two types of wamples were taken at each of the sampling locations; radon concentration and working level. The radon concentrations were taken by collecting filtered air samples in vacuum flasks. These samples were then transferred into "Lucas celis" at the base station, and were counted in an appropriate counter. The "Lucas Cell" is an alpha scintillation chamber which consists of a glass container coated on the inside with a silver-activated zinc sulfide mixture. This mixture is a phosphor which emits light when excited by alpha particles. The light. pulses are then counted through a window in the chamber using a photomultiplier detector, yielding the radon concentration in picocuries per liter ( $\mathrm{pCi} / \mathrm{l}$ ). The working level is a measure of the combination of 
the alphactivity of the radon daughters in air. The working level is measured by drawing air through an appropriate filter for a set length of time (10 minutes was used in this study), and then counting the alpha activity with an alpha filter counter using defined decay and counting intervals. In this study both the Rolle method ard the modified kusnetz method were used for comparison. Reference 2 details these techniques; along with that used for the radon measurement.

The main difficulty in attempting to make these measurements is that the techniques are not extremely sensitive. They were originally intended for uranium mining and other situations where there would be significant levels of radon and its daughters. As an example of this, for the systems used in this survey, the background in the radon counter was only $0.94 \mathrm{cpm}$, which corresponds to a critical level at which detection can be assumed of $3.6 \mathrm{pCi} / 1$. Similarly, the background in the alpha filter counter was only $0.1 \mathrm{cpm}$, which this corresponds to critical level of $0.7 \mathrm{mWL}$ for the Rolle and $1.0 \mathrm{mWL}$ for the Kusnetz method (assuming that the daughters are in equilibrium with the radon these measurements could be used to estimate radon also, at a value of 100 $\mathrm{pCi} / \mathrm{l} / \mathrm{WL}$, yielding $0.1 \mathrm{pCi} / 1$ ). These levels are high enough to present difficulies in attempting to make the measurements proposed in this study, as will be seen; however, the equipment nesessary to achieve higher sensitivities was not available in the time span necessary to meet the schedule of this study. Feference 3 details the method for deternining the critical, determination, and quanitative levels for a counting system.

As an alternative method for estimating the radon concentration, another method was used combining results from both the radiation field study and the grab sample study. The radium concentrations in soil estimated from the radiation field study result from a measurement of the photons from the radium daughters, since the photon directly from radium is normally too weat to observe directly. In reality, these daughter peaks combine contributions from the daughters in the soil and from the daughters in the air. If the soil. sample from the grab sampling is assumed to be characteristic of the site (a reasonable assumption since the total variation of all the surface samples is only $20 \%$, then the ratio of the two values at a given location represents the fraction of the signal from the daughters in the air. By inserting this fraction and the appropriate values into equation 4 for air rather than soil, the airborne concentration of the daughters can be estimated. The radon concentration can be estimated by approximating the fractional equilibrium with the daughters, which is probably on the order of $10-$ $30 \%$ under disturbed atmospheric conditions results of the air sampling survey along with the estimates based upon the radiation field analysis study,

\section{DISCUSSION OF THE RESULTS}

Tables 1, 2, and 3 contain the results obtained during this sampling program, and present a detailed description of the site, both on the surface and in the mine. On the surface it was found that radium, and 
hence its parent uranium, occurred in concentrations averaging 0.25 pCilgm at all locations, with a variation of $20 \%$. This accounts for about $64 \%$ of the dose rate on the surface, not including the radon and daughters in the air. The radon concentration in air is estimated to be about $0.01 \mathrm{pCi} / 1$ (based on the method described in the previous paragraph, assuming $10 \%$ equilibrium with the daughters and would then contribute only about $0.2 \%$ to the dose rate. The potassium-40 in the soil appears quite uniform at about $10.2 \mathrm{pCi} / \mathrm{gm}$ (5.6\% variation), and contributes about $28 \%$ of the dose rate. Cesium-137 from atmospheric weapons testing fallout was observed in about $64 \%$ of the soil samples at Ievels of about $0.13 \mathrm{pCi} / 9 \mathrm{~m}$, with a $31 \%$ variation, accounting for about 8\% of the dose rate on the average. These totaled out to yield an average calculated dose rate of $7.6 \mathrm{~J}$ urem/hr, comparing well with the pressurized ion chamber average of $7.65 \mathrm{uR} / \mathrm{hr}$, and the 5.5 year average for the SNLA TLD survey of 8.10 urem/hr.

In the mine, the dose rate appearg to be coming entirely from potassium-40, probably from within the salt bed. Unfortunately, the $k-40$ level in the salt gamples are at about the minimum sensitivity of our detector with its present shielding. The estimated dose rates in the mine are somewhat higher than those measured with the ion chamber (although at those levels a factor of $1.5-2$ is insignificant for either instrument), however the difference is probably due to deviations in the geometry from the infinite source assumed in equation 4 and uncertainties in equipment calibration at such low levels.

The aimorne activity measurements all were found to be at or below the minimum detectable levels for our instruments, undoubtably due to the low uranium concentration observed in the soil. Only under the worst possible condition, of no ventilation in the south drift of the mine. were radon levels found that even approached the detection limits (with a critical level of $Z \mathrm{pCi} / 1$, the detection limit is $15.5 \mathrm{pCi} / 1$ ). This is very promising in evaluating the interference of the radon daughters upon the response of the proposed plutonium alpha air monitoring system.

One final comment should be made about the radiation field measurements in the mine. In several of the spectra in the mine, there appeared to be traces of Cobalt-6o. Although the levels were very low, this caused some concern as to its origin, since it could be positively identified. It was decided that this was probably coming from the detector itself. Co-60 is a minor impurity in steel due to its use for a tracer in wall linings of blast furnaces; however it was never expected to be observable. The extremely low radiation levels found in the mine, lower. than the levels found in most counting shields, apparently allowed us to observe the trace impurities in the steel of the detector"s own liquid nitrogen dewar.

\section{CONCLUSIONS}

Most of the results found in this study can speak for themselves. They provide a good characterization of the site background radiation levels and madionuclides. Most of the findings will not change significantly 
with time, except for the airborne radionuclide levels. This mtudy then provides a baseline for evaluation of changes in the background due to the influence of the site itself. However, this type of survey is too complex to be repeated except at rare intervals, especialiy since simpler measurements will provide the necessary indicators for gross changes in the environmerit due to the site. A reasomable approach would be to maintain a series of TLD stations, similar to the ongoing Sandia National Laboratories TLD survey in progress, and support that with an annual grab sampling program for verification. Only if long term trends in the TLD surveys or unLisual findings in the grab sampling identify changes from the baseline should a survey of this type be repeated.

The air monitoring for radon and its daughters should be approached separately from the comments above. There can be significant changes in these levels due to a variety of conditions, and this should be evaluated further to determine its full potential for interfering with the plutonium air monitoring program. Based upon the observations made in this study the radon and radon daughter levels appear to be very low, but under different seasonal or meteorological conditions their levels could vary significantly. It is therefore recommended that the radon and radon daughter concentrations be studied over a longer term iminimum of a year) in order to reach a better understanding of the radon potential at the site. There are techniques and equipment available that are more sensitive trian those chosen for this study that would permit reliable measurement of the levels estimated by this study. 


\section{REFERENCES:}

1. Brodsky, Allen. Ed. , Handbook of Radiation Measurement and Protection, section $A$, volume II Eiological and Mathematical Information, CFC Fress, Inc., 1982, Table 6.4-12, 401-403.

2. IAEA/ILO Fublication No. 43, Manual on Fadiological Safety in Uranium and Thorium Mines and Mills, 1976.

Specific references for Fiadon and Fadon daughter measurements:

(a) Lucas, H. F., Improved Low-Level Alpha Scintillation Counter for Fadon, Fiev. Sci. Instrum., vol. 28, 680, 1957.

(b) Kusnetz, Hu L., Fadon Daughters in Mine Atmospheres - A Field Method for Determining Concentrations: Am. Ind. Hyg. Assoc. Journal, vol 17, 153, 1969.

(c) Folle, F., Improved Fadon Daughter Monitoring Frocedure, Am. Ind. Hyg. Assoc. Joumnal, vol 30-2, 153, 1969.

(d) Folle, Fi., Fapid Working Level Monitoring. Health Physics Journal, vol 22-3, 233, 1972 .

3. Currie, L. A., Limits for Qualitative Detection and Quantitative Determination, Application to Fadiochemistry, Analytical Chemistry, vol $40-3,586,1968$.

4. Brewer, L. W. and Metcalf, J. H., "Environmental Monitoring at the WIPP Site -- CY 1976", SAND 77-1021; and unpublished data for CY 1977 to present. 
Table 1

Grab Sample Vs. Radiation Field Spectra Fesults

Location

ERDA 6

AEC 7

AEC 8

ERDA 9

WIPP 11

$$
\begin{gathered}
P b-212 \\
P b-214 \\
B i-214 \\
k-40 \\
C s-137
\end{gathered}
$$

Badger

$$
\begin{gathered}
F b-212 \\
F b-214 \\
E j-214 \\
K-40 \\
C s-137
\end{gathered}
$$

Met. Stat.

\section{Soil Sample $(\mathrm{pCi} / \mathrm{g})$}

$$
\begin{array}{ll}
0.13 & (23 \%) \\
0.09 & (21 \%) \\
0.27 & (15 \%) \\
0.17 & (19 \%) \\
9.74 & (7 \%)
\end{array}
$$

$$
\begin{array}{cl}
0.22 & (14 \%) \\
0.27 & (16 \%) \\
0.28 & (16 \%) \\
1.1 .3 & (6 \%) \\
0.09 & (23 \%)
\end{array}
$$
$0.20(35 \%)$
$0.08(20 \%)$
$0.25(14 \%)$
$0.27(3.3 \%)$
$10.1(6 \%)$

$$
\begin{aligned}
0.21 & (12 \%) \\
0.20 & (19 \%) \\
0.30 & (32 \%) \\
10.0 & (6 \%)
\end{aligned}
$$

$$
\begin{array}{ll}
0.14 & (19 \%) \\
0.18 & (20 \%) \\
0.20 & (18) \\
9.6 & (6 \%) \\
0.19 & (14 \%)
\end{array}
$$

$0.14(18 \%)$

$0.24(14 \%)$

$0.27(36 \%)$

$9.4 \quad(6 \%)$

$0.10(18 \%)$

$0.26(11 \%)$

$0.25(18 \%)$
Radiation Field
(pCi/g)

$($ notes 1,2$) \quad N . D$.

N.D.

N.D.

0.93

7.4

N.D.

$N, D$.

N.D.

11.1

N. D.

N.D.

N.D.

N.D.

1.5

1.3 .0

N.D.

$N=D$.

0.93

9.93

N.D.

$N$. D.

1. 0

9.6

N. D.

$N$ " $D$.

$N . D$.

2. 0

13.5

$N \cdot D$.

$N \cdot D$.

$N$. D. 
Loc at i on

$$
\begin{aligned}
& \text { Isotope } \\
& \text { Ei }-214 \\
& k-40 \\
& \cos -157
\end{aligned}
$$

NW Cor.

$$
\begin{gathered}
P b-212 \\
F b-214 \\
B j-214 \\
k-40 \\
C s-137
\end{gathered}
$$

SW Cor.

$$
\begin{gathered}
F b-212 \\
F b-214 \\
k-40
\end{gathered}
$$

NE Cor.

$$
\begin{gathered}
\text { Pb-212 } \\
T l-208 \\
F b-214 \\
\text { Bi }-214 \\
k-40 \\
C s-137
\end{gathered}
$$

Vent.

$$
\begin{gathered}
F b-212 \\
F b-214 \\
B i-214 \\
k-40
\end{gathered}
$$

$$
\begin{array}{ll}
\text { E140/N780 } & k-40 \\
\text { E140/53650 } & k-40
\end{array}
$$

\author{
Sol. 1 Sample \\ $(p C i / q)$
}

$$
\begin{aligned}
0.24 & (15 \%) \\
10.9 & (6 \%) \\
0.15 & (16 \%)
\end{aligned}
$$

$0.15(16 \%)$

$0.20(15 \%)$

$0.27(26 \%)$

$10.0 \quad(6 \%)$

$0.08(21 \%)$

$$
\begin{array}{ll}
0.17 & (14 \%) \\
0.17 & (23 \%) \\
0.8 & (6 \%)
\end{array}
$$

$$
\begin{array}{cl}
0.22 & (11 \%) \\
0.07 & (23 \%) \\
0.20 & (14 \%) \\
0.1 & (18 \%) \\
10.3 & (6 \%) \\
0.14 & (15 \%)
\end{array}
$$

$$
\begin{aligned}
0.21 & (14 \%) \\
0.39 & (10 \%) \\
0.32 & (14 \%) \\
10.5 & (6 \%)
\end{aligned}
$$

\section{Radiation Field} ( $\mathrm{pCi} / \mathrm{g}$ )

$$
\begin{aligned}
& N . D . \\
& N . D . \\
& N . D .
\end{aligned}
$$

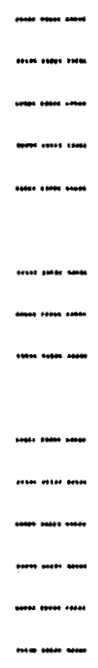

N.D.

$N, D$.

0.81

7.3

\section{NOTES:}

1. The uncertainties quoted are one standard deviation and are based on counting statistics and calibration errors summed in quadrature.

2. For the radiation field estimates, no uncertainties have been assigned to the values at the present, wince the technique used is still under evaluation. Also, N.D. indicates that the corresponding isotope was not detected in the spectra, and "---" indicates that no spectra was run that location.

3. The values quoted for $k-40$ are after subtracting background. However, there is some uncertainty as to the actual background value. 
WIPP Radiation Survey

\section{Table 2}

Calculated Dose Rate from Soil Compared to Measumed Dose Fate

Location: Mine outlet Shaft

Isotope

Cumcentration

$$
(p \mathrm{Ci} / g \text { ) }
$$

Calc. Dose Rate (urem/hr)

$\operatorname{Ria}-226(1)$

$k-40$

$\mathrm{Cs}-1.37$

$$
0.55
$$

10.5

N. D.
6.8

2.2

$-$
Fraction of Total

0.76

0.24

Total Calculated Dose Rate $=9.0$ urem $/ \mathrm{hr}$

Reuter-Stokes FIC (2) $=7.5 \mathrm{LFihr}$

$T L D$ (I) $=N . A$.

Location: ERDA \#9 TLD site

Isotope Concentration

$$
\text { (pCi/g) }
$$

0.25

10.0

N.D.

$k-40$

Cs-1.37
Calc. Dose Rate (urem/hm)

4.9

2.1

$-$

Fraction of Total

Total Calculated Dose Fate $=7.0 \mathrm{urem} / \mathrm{hr}$

Reuter-Stokes FIC $=7.2 \mathrm{LR} / \mathrm{hr}$

$T L D=8.1$ urein/hr

Location: WIFP \#11 TLD Site

Isotope

Concentration $(p C i / g)$
Calc. Dose Rate (urem/hr)

Fraction of Total

0.70

0.30
$R a-226$
0.20
3.9
2.0
9.6
1. 4
0.53
0.27
0.19
$1 ;-40$
$C s-137$
0.19

1.4

Total Calculated Dose Fate $=7.3 \mathrm{urem} / \mathrm{hr}$

Reuter-5tokes FIC $=7.4 \mathrm{LR} / \mathrm{hr}$

TLD $=7.2 \mathrm{urem} / \mathrm{hr}$ 
Table 2 (cont.)

Location: AEC \#7 TLD Site

$\begin{array}{cccc}\text { Isotope } & \begin{array}{c}\text { Concentration } \\ (\mathrm{pCi} / \mathrm{g})\end{array} & \begin{array}{c}\text { Calc. Dose Rate } \\ \text { (urem/hr) }\end{array} & \text { Fraction of } \\ \text { Ra-226 } & 0.30 & 5.9 & 0.60 \\ 6-40 & 1.3 & 2.3 & 0.26 \\ C 5-1.37 & 0.09 & 0.7 & 0.08\end{array}$

Total Calculated Dose Fate $=8.9$ urem $/ \mathrm{hr}$

Reuter-5tokes FIC $=8.5 \mathrm{LF} / \mathrm{hr}$

$T L D=8.8$ urem/hr

Location: ERDA \#O TLD Site

Isotope

Concentration $(p C i / g)$

Calc. Dose Fiate (urem/hr)

$\begin{array}{ll}R a-22 b & 0.25 \\ K-40 & 9.7 \\ C s-1.37 & \text { N.D. }\end{array}$

4.9

2.0

$-$

Fraction of Total

$$
\begin{aligned}
& 0.71 \\
& 0.29
\end{aligned}
$$

Total Calculated Dose Rate $=6.9 \mathrm{urem} / \mathrm{hr}$

Reuter--Stokes FIC $=8.5 \mathrm{uR} / \mathrm{hr}$

$T L D=8.3$ urem/hr

Location: AEC \#B TLD Gite

Isotope

Concentration (pCi/g)

$$
0.26
$$

10.1

N.D.

$C s-137$
Calc. Dose Rate (urem/hr)

5.1

2. 1

$-$

Fraction of Total

$$
\begin{aligned}
& 0.71 \\
& 0.29
\end{aligned}
$$

Dose Rate $=7.2$ urem/hr

Total Calculated Dose Rate $=$
Reuter-Stokes FIC $=8.5 \mathrm{uR} / \mathrm{hr}$

$T L D=8.3$ urem/hr

Location: Badger TLD Site

Isotope Concentration ( $p C i / g$ )
0.26
9.4
0.10

Calc. Dose Fate (urem/hr)
Fraction of Total

5.1

2.0

0.7
0.65

0.26

0.09

Total Calculated Dose Rate $=7.8$ urem/hr

Reuter-Stokes PIC $=8.0 \mathrm{uR} / \mathrm{hr}$

$T L D=8.4$ urem/hr 
Table 2 (cont..)

Location: Metro Station TLD Site

I sotope

Concentration $(p C i / g)$

$\operatorname{Ra}-226$

K- -40

$\mathrm{C} s-137$
0.25

10.9

0.13
Calc. Dose Rate (urem/hr)
4.9

2.3

1.0
Firaction of Total

0.60

0.28

0.12

Total Calcul ated Dose Rate $=8.2 \mathrm{urem} / \mathrm{hr}$ Reuter-Stokes FIC $=7.5 \mathrm{uR} / \mathrm{hm}$

TLD $=7.6$ urem/hr

Location: WIFP Site NW corner outside of fenced area

Isotope

Concentration

$$
\langle p C i / g\rangle
$$

Ra-226

$k-40$

$\mathrm{Cs}-1.37$
0.24

10.0

0.09
Calc. Dose Rate (urem/hr-)
4.7
2. 1
0.6

Fraction of Total

0.64

0.28

0.08

Total Calculated Dose Rate $=7.4 \mathrm{urem} / \mathrm{hr}$

Reuter-Stoles PIC $=8.0 \mathrm{uR} / \mathrm{hr}$

$T L D=N_{n} A_{n}$.

Location: WIFF Site NE Corner outside Fenced Area

Isotope Concentration Calc. Dose Rate
$(p C i / g)$ (urem/hr) Fraction of Total
$R a-226$
Ḱ-40
$C s-137$
0.20
10.3
0.14
3.9
2.1
1.0
0.56
0.30
0.14

Total Calculated Dose Fiate $=7.0$ urem $/ \mathrm{hr}$

Reuter-Stokes FIC $=8.0 \mathrm{LR} / \mathrm{hr}$

$T L D=N . A_{1}$

Location: WIPP Site SW Corner outside fenced area

Isotope Concentration Calc. Dose Rate Fraction of total (pCi/g) (urem/hr)
$R a-226$
0.20
9.8
I.9
0.54
$k-40$
0.17
2.0
0.28
$C s-1.37$
1.3
0.18

Total Calculated Dose Rate $=7.2$ urem/hr Reuter-5takes FIC $=5.0 \mathrm{uR} / \mathrm{hr}$ $T L D=N . A$. 
Table 2 (cont.)

Location: WIFF Mine at E140"185650"

\begin{tabular}{|c|c|c|c|}
\hline Isotope & $\begin{array}{c}\text { Concentration } \\
(p \mathrm{Di} / g)\end{array}$ & $\begin{array}{c}\text { Calc. Dose Rate } \\
\text { (urem/hr) }\end{array}$ & Fraction \\
\hline $\begin{array}{l}R a-226 \\
K-40 \\
C 5-137\end{array}$ & $\begin{array}{l}\text { N.D. } \\
1.9 \\
\text { N.D. }\end{array}$ & $\begin{array}{l}0.0 \\
0.8 \\
0.0\end{array}$ & $\begin{array}{r}0.0 \\
100.0 \\
0.0\end{array}$ \\
\hline
\end{tabular}

Total Calculated Dose Fate $=0.8 \mathrm{urem} / \mathrm{hr}$

Reuter-Stoles FIC $=0.6 \mathrm{uR} / \mathrm{hr}$

$T L D=N_{1} A_{\text {. }}$

Location: WIFF Mine at E140\%/S1607"

$\begin{array}{lccr}\text { Isotope } & \begin{array}{c}\text { Concentration } \\ (\mathrm{pCi} / g)\end{array} & \begin{array}{c}\text { Calc. Dome Rate } \\ \text { (urem/hr) }\end{array} & \text { Fraction of } \\ \text { Ra-226 } & \text { N.D. } & 0.0 & 0.0 \\ \text { K-40 } & 2.9 & 1.21 & 100.0 \\ \text { Cs-137 } & \text { N.D. } & 0.0 & 0.0\end{array}$

Total Calculated Dose Fate $=1.21 \mathrm{urem} / \mathrm{hr}$

Reuter-Stokes FIC $=0.7 \mathrm{uR} / \mathrm{hr}$

$T L D=N \cdot A$.

Location: WIFF Mine at E140\%/N140\%

Isotope

Concentration

$(p C i / g$ )

$\operatorname{Ra}-226$

$K-40$

$C 5-137$

N. D.

2. 2

N.D.
Calc. Dose Rate (urem/hr)

0.0

0.92

0.0

Fraction of Total

Total Calculated Dose Fate $=0.92 \mathrm{urem} / \mathrm{hr}$

Reuter-Stokes FIC $=0.6 \mathrm{uR} / \mathrm{hr}$

$T L D=N_{1} A_{\text {. }}$

Location: WIFF Mine E140" /N780"

Isotope

Concentration ( $p C i / g$ )

Ra-226

$k-40$

$\mathrm{Cs}-137$
N.D.
3.5
N.D.

Calce Dose Rate (urem/hr)

0.0

1.46

0.0
Fraction of Total

$$
\begin{array}{r}
0.0 \\
100.0 \\
0.0
\end{array}
$$

Total Calculated Dose Rate $=1.46 \mathrm{urem} / \mathrm{hr}$ Reuter-Stolees FIC $=0.7 \mathrm{uF} / \mathrm{hr}$

$T L D=N . A$. 
Table 2 (cont.)

Location: WIFP Mine at E140" /N1450"

Isotope Concentration
$(p C i / g)$ Calc. Dose Rate Fraction of Total

$\begin{array}{llcr}R=226 & \text { N.D. } & 0.0 & 0.0 \\ K-40 & 2.2 & 0.92 & 100.0 \\ C s-137 & \text { N.D. } & 0.0 & 0.0\end{array}$

Total Calculated Dose Fate $=0.92 \mathrm{urem} / \mathrm{hr}$

Reuter-Stokes FIC $=0.7 \mathrm{uF} / \mathrm{hr}$

$T L D=N \cdot A$.

NOTES:
$N_{*} D_{*}=$ not detected
N. $A_{0}$ = not available

(1) Radium-22b concentration inferred from assuming lequilibrium with $\mathrm{Fb}-214$ and Ei-214 daughters.

(2) Reuter-Stokes FIC refers to the Reuter-Stokes pressurized ion chamber measurements taken in this study.

(3) TLD refers to the 5.5 year averages of the SNLA TLD survey program continuing at the site (reference 4 ).

(4) The potassium-40 values used for the salt concentration in the mine are the estimated values from the radiation field spectra study. 
Table 3

Fadon and Working Level Fiesults

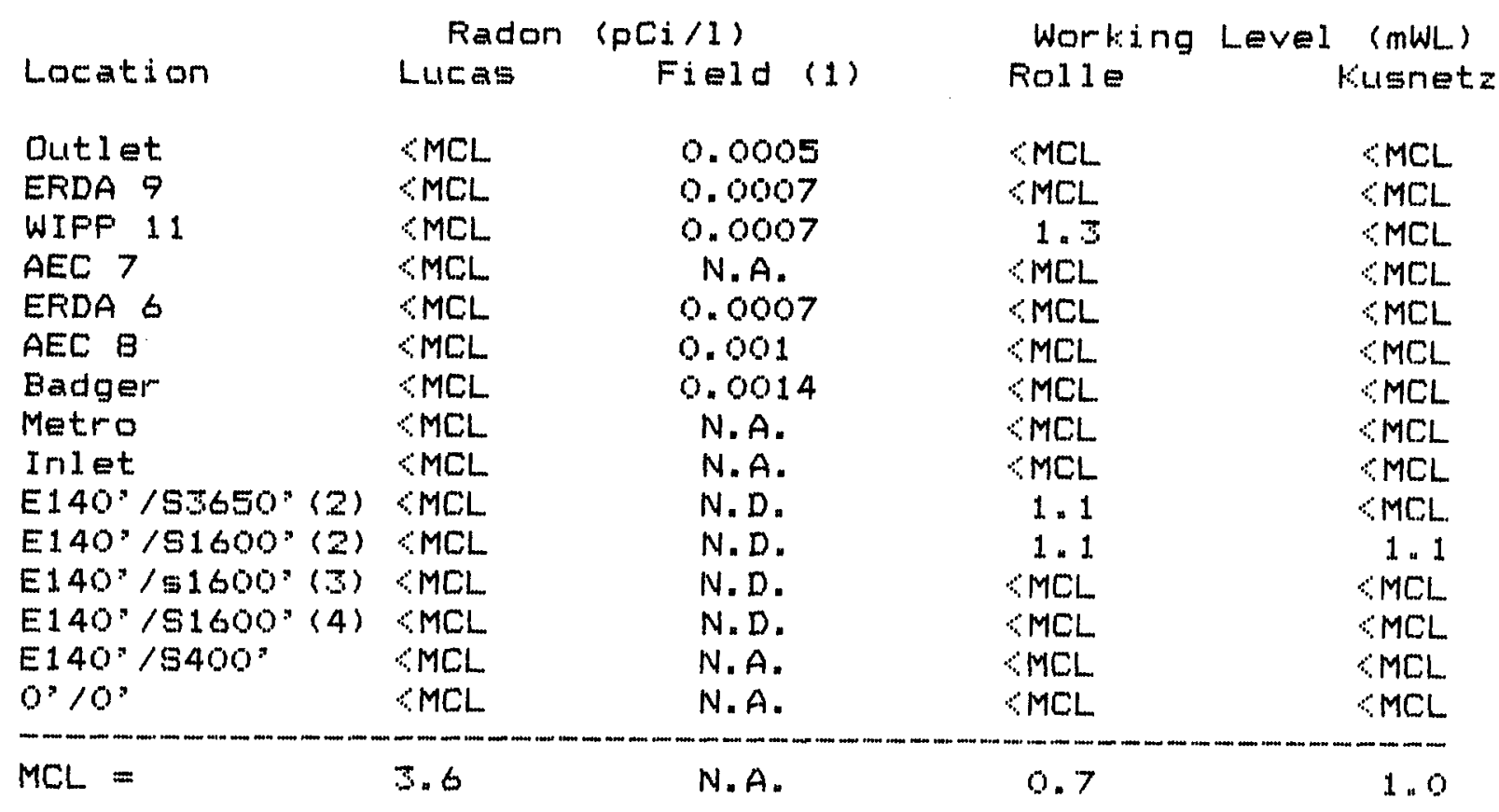

NDTES:

(1) "Lucas" represents the "Lucas" cell methodology, and "field" represents the estimate from the radiation field spectra.

(2) The booster fans used for circulating air in this shaft were not turned on for these measurements.

(3) One booster fan was turned on, representing normal conditions in this shaft.

(4) Eoth booster fans were turned on, a condition used with high vehicular activity in this shaft. 
AFPENDIX 1: Spectral Fesults 


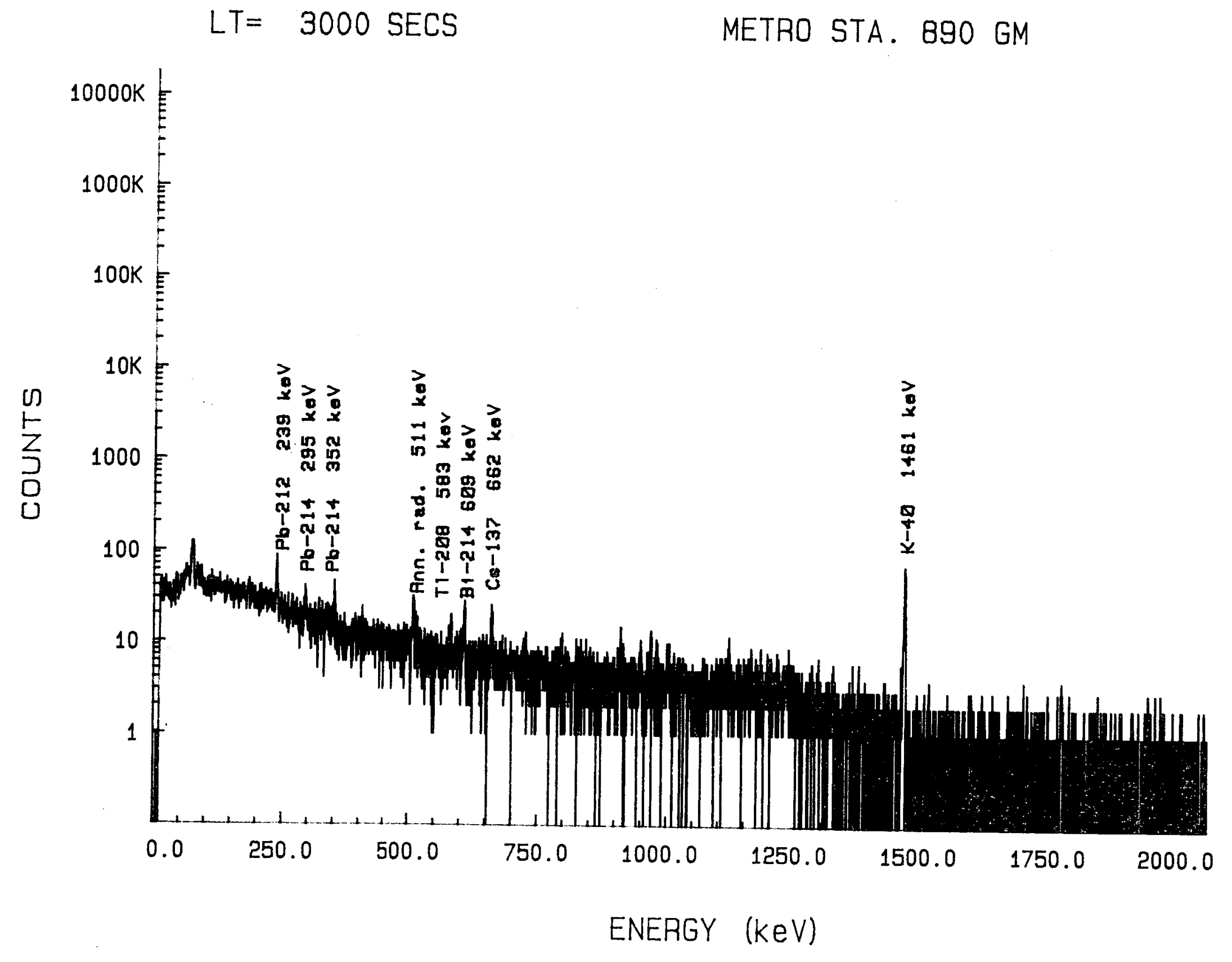




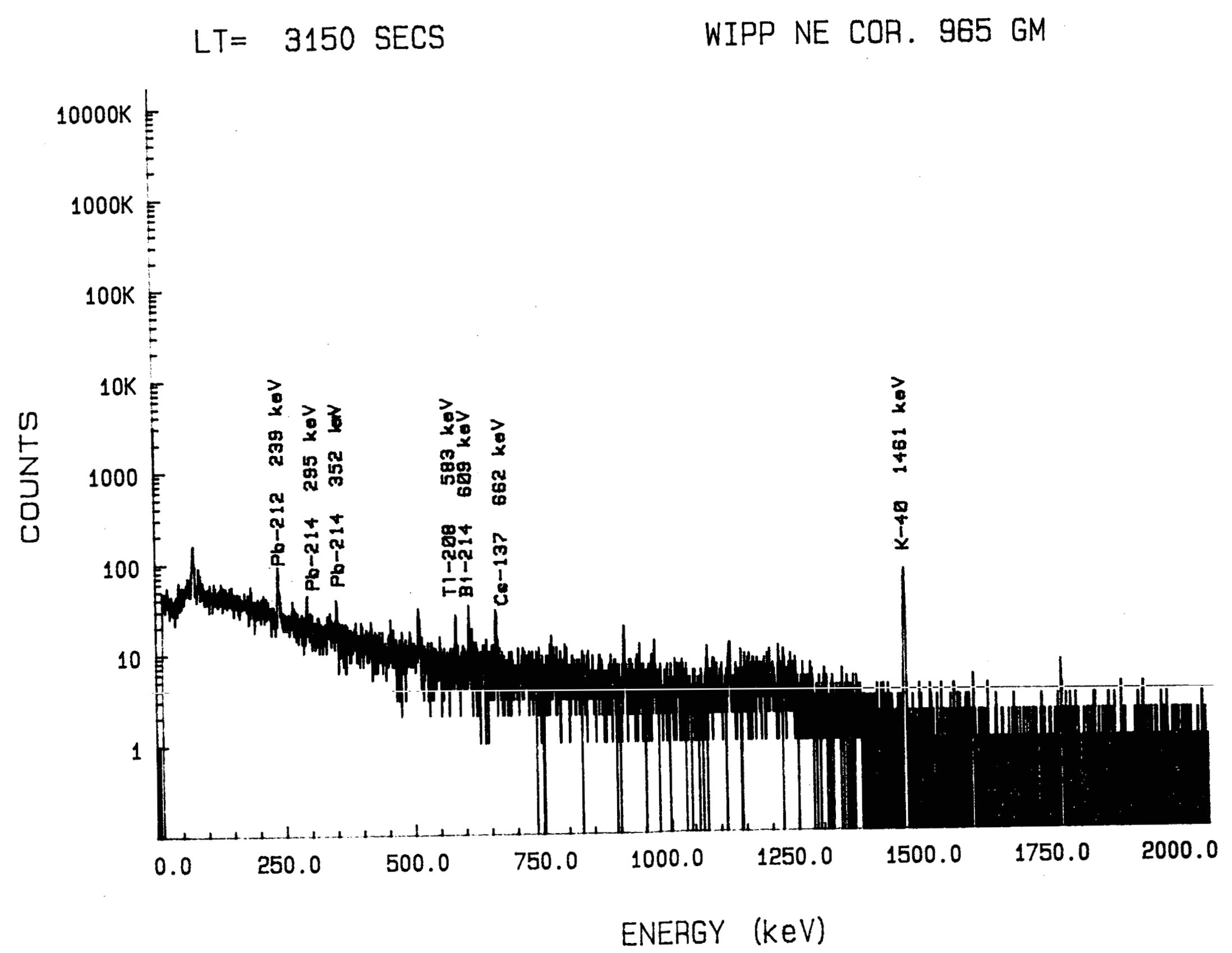


$L T=3000$ SECS

WIPP SW COR. 905 GM

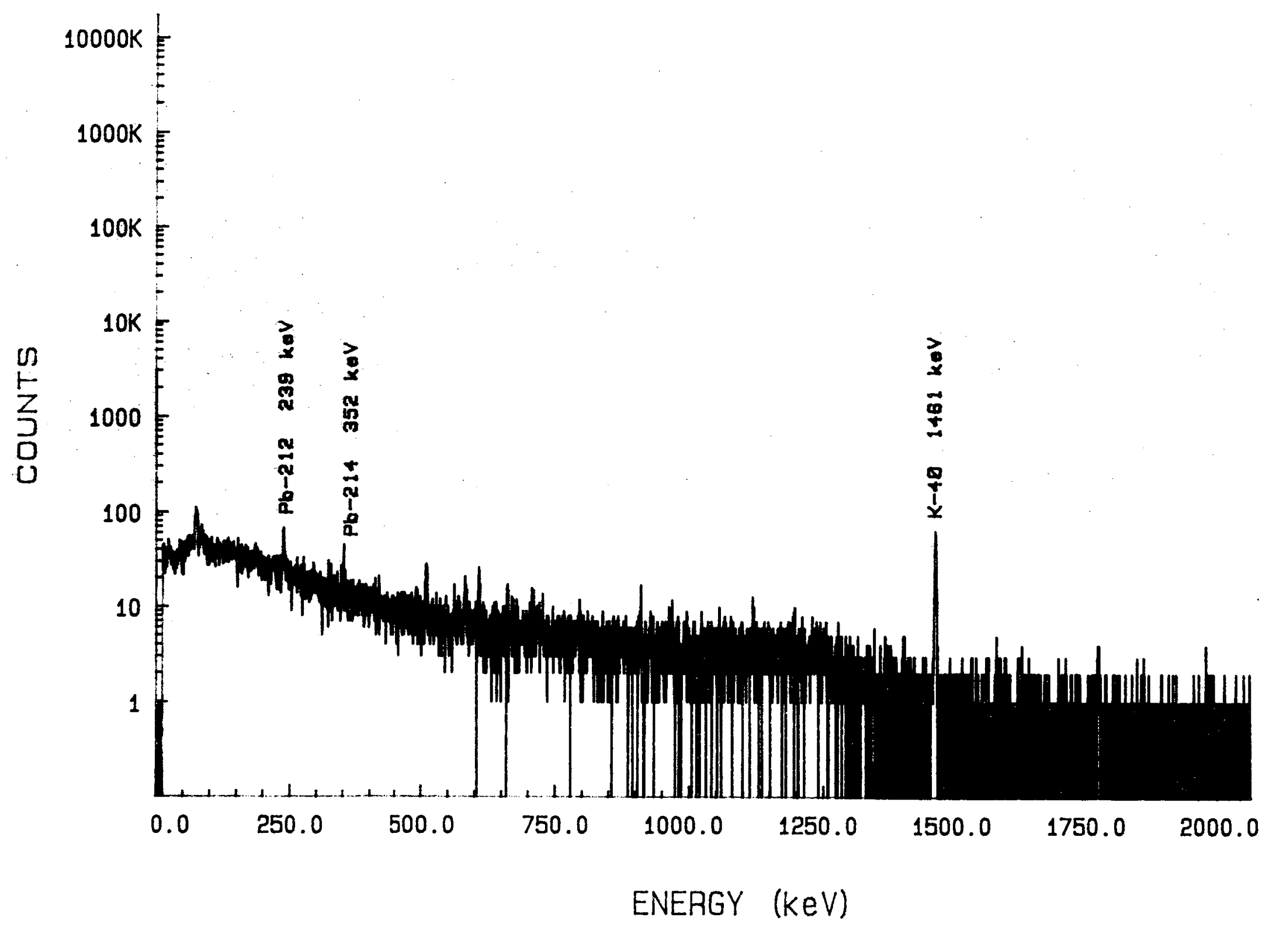



$L T=3000$ SECS
WIPP NW COR. 963 GM

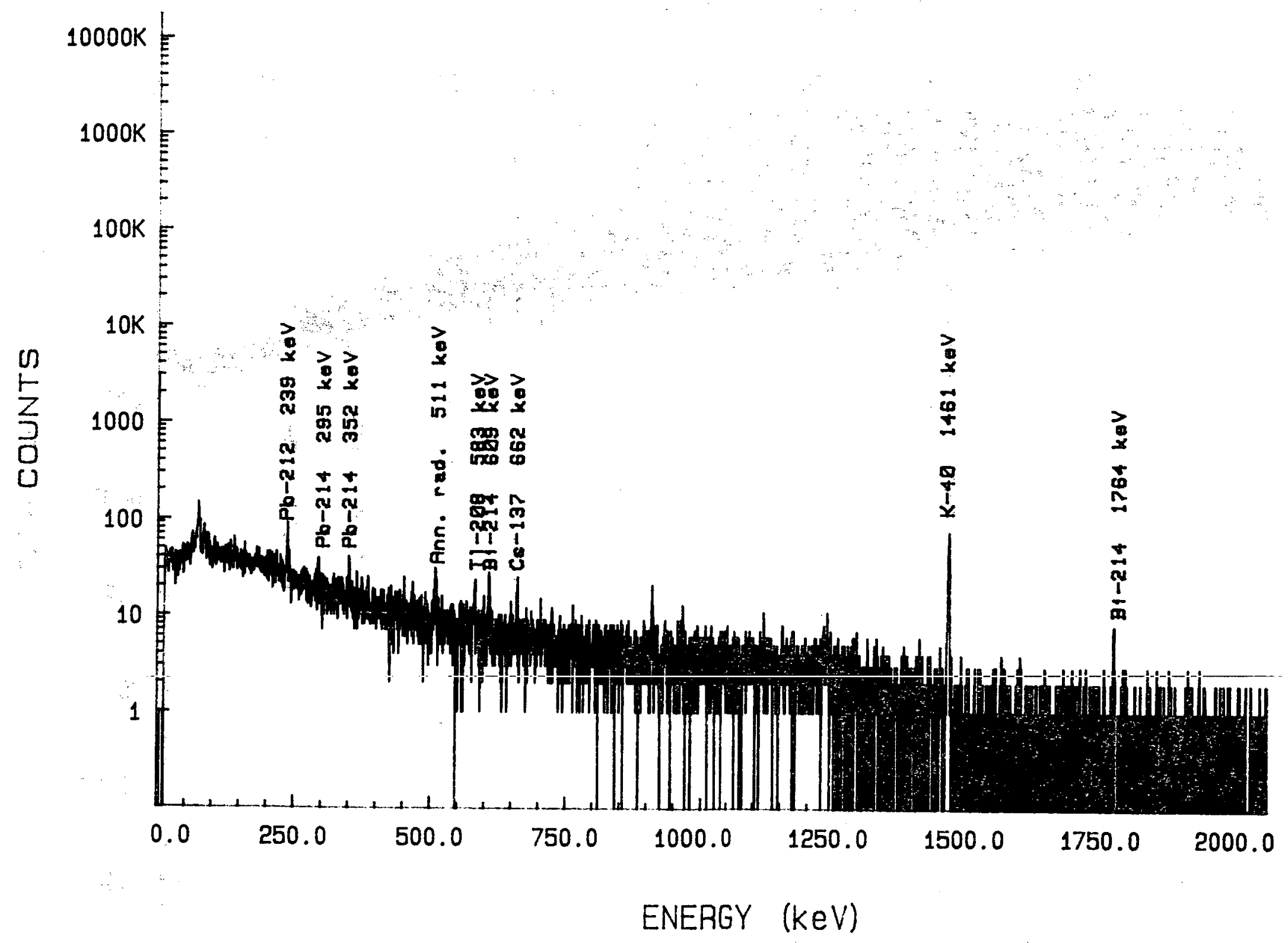




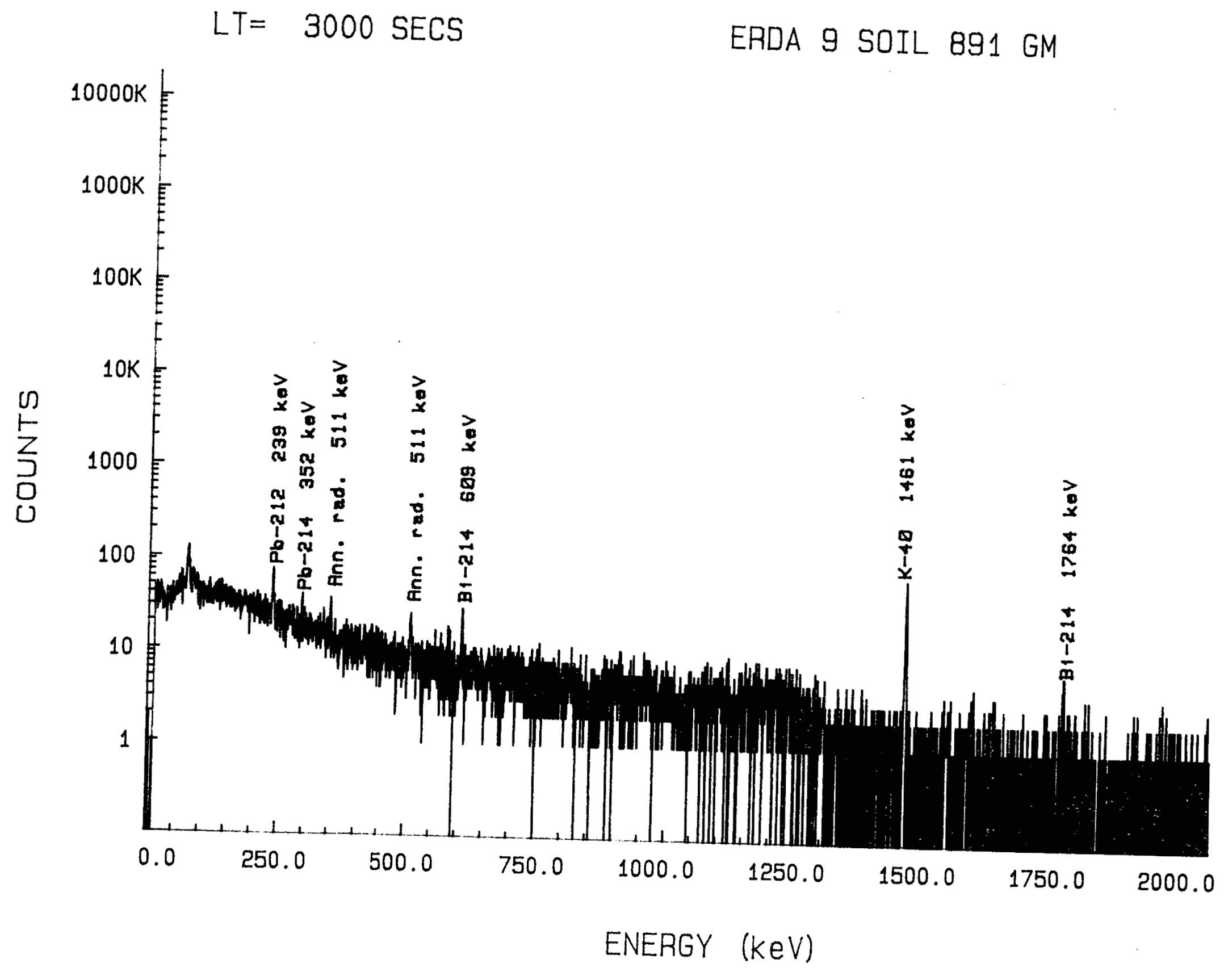




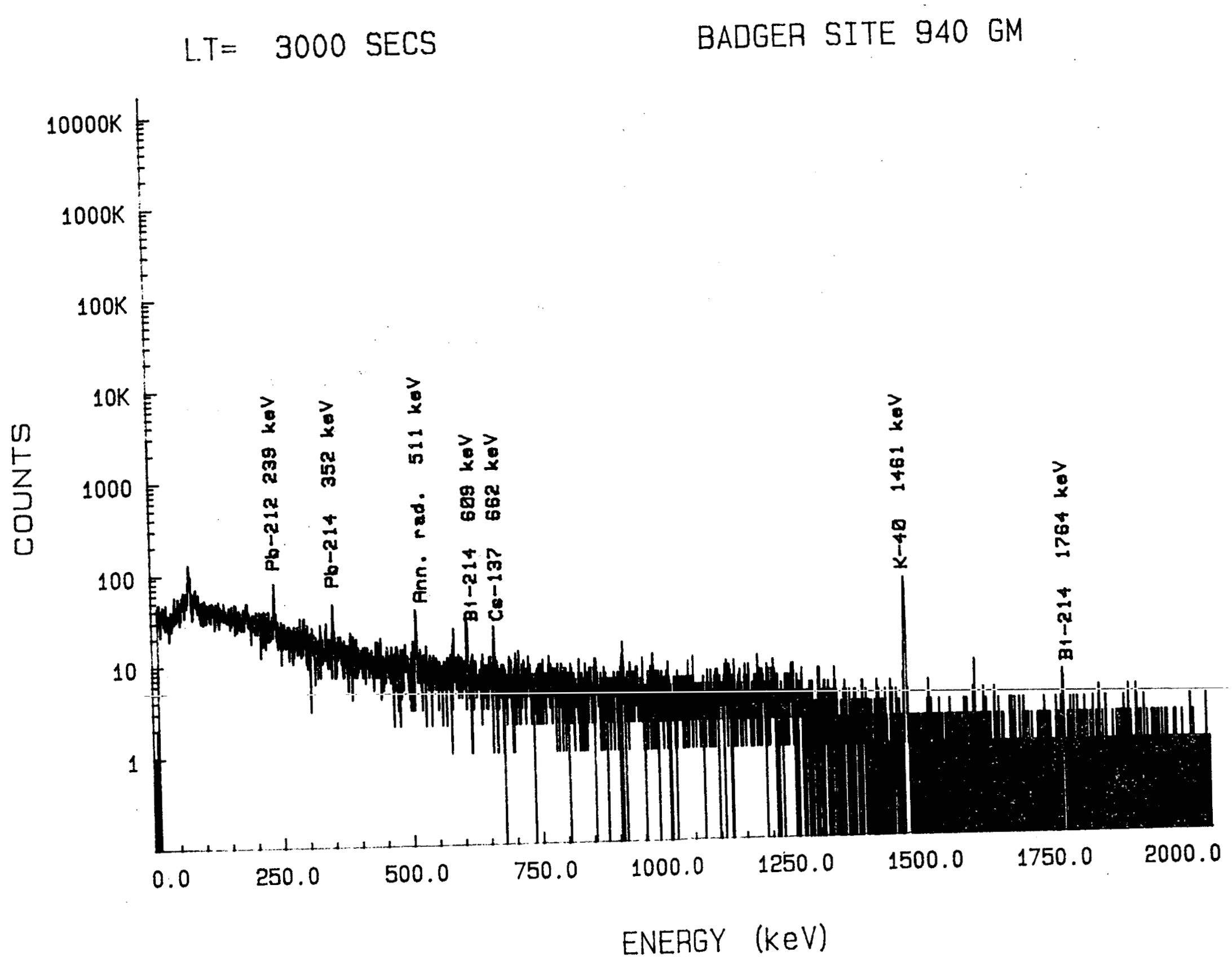


$L T=2000$ SECS BADGER RAD FIELD

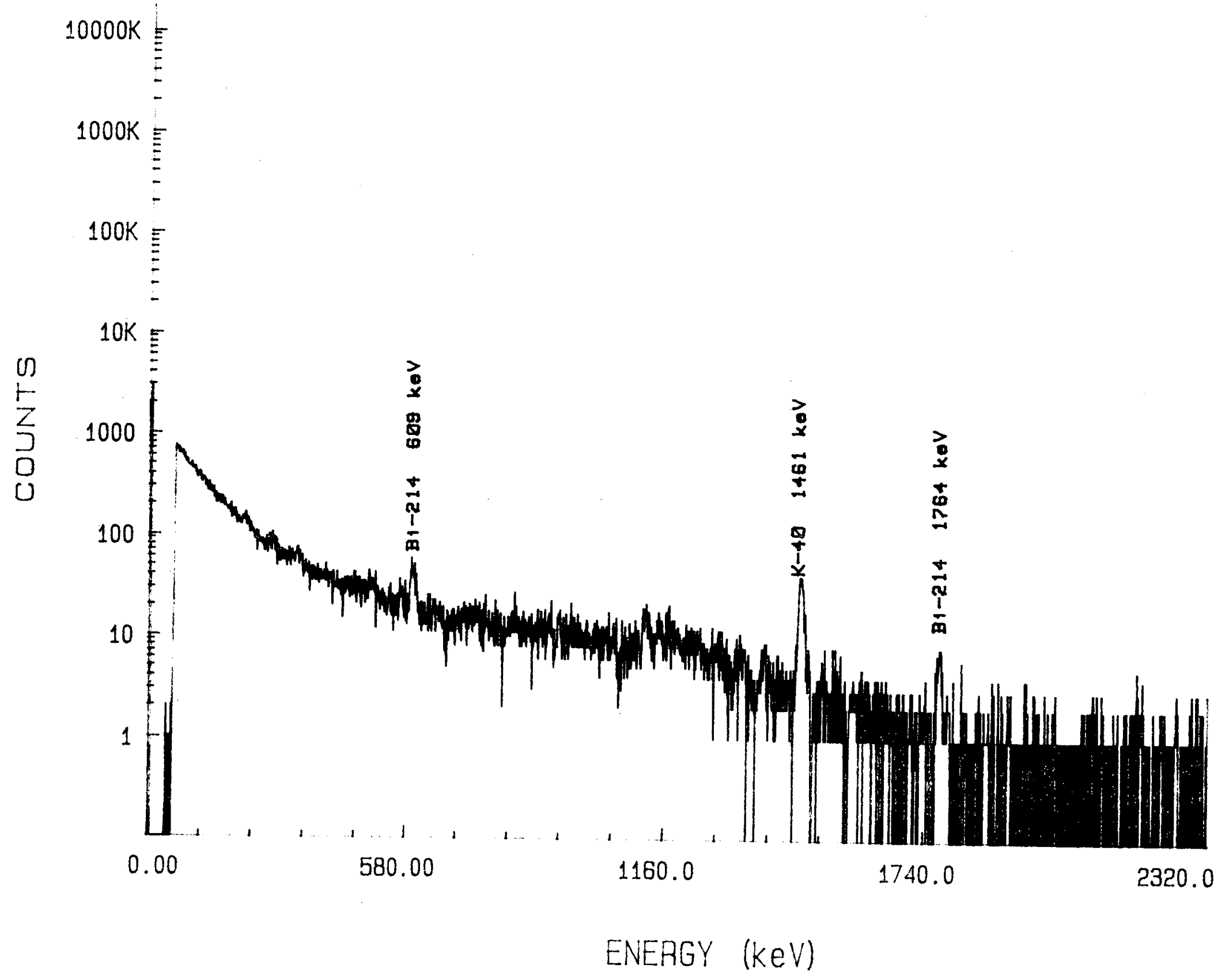




$$
L T=3000 \text { SECS WIPP } 11 \text { SOIL } 880 \text { GM }
$$

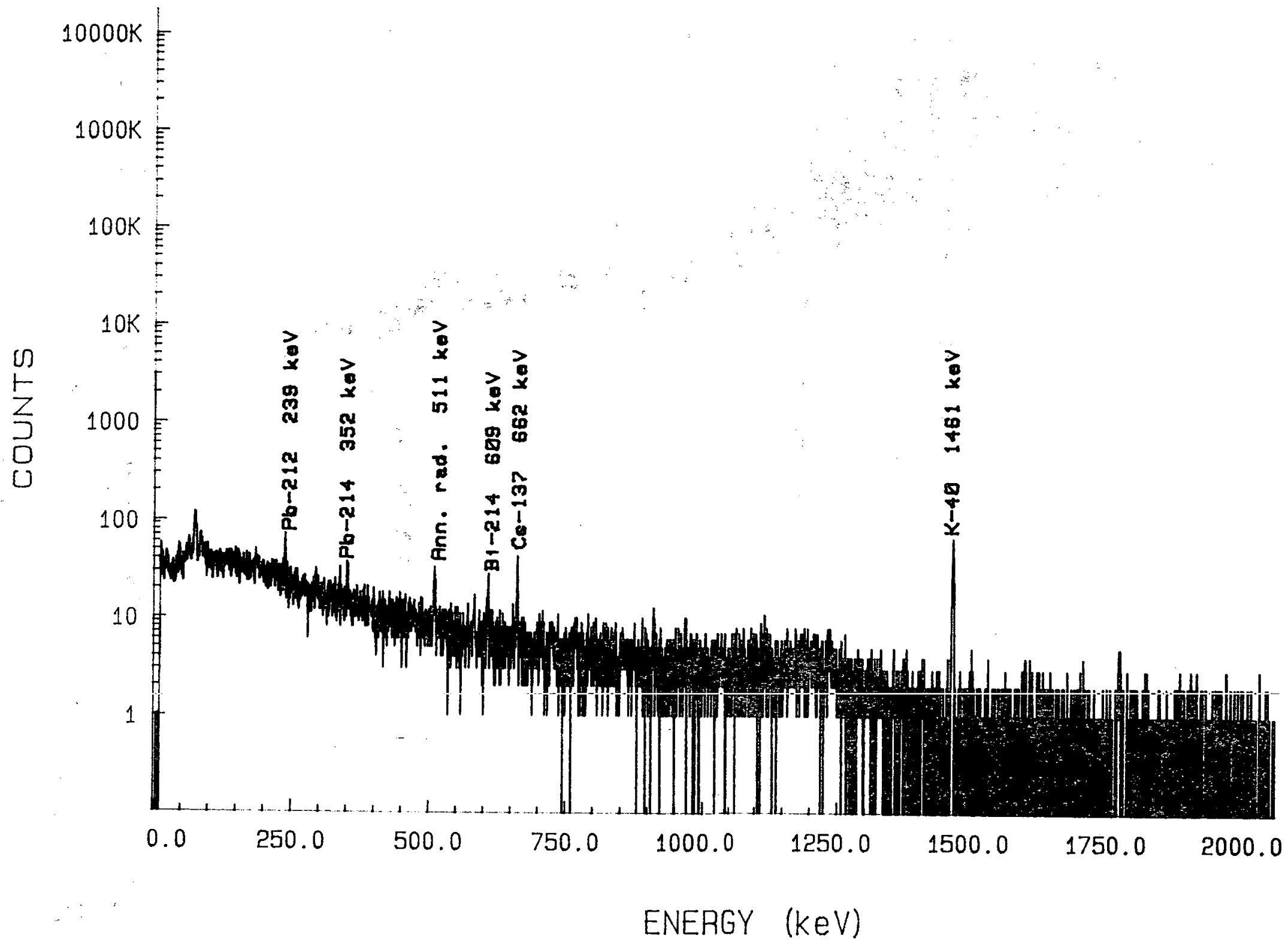


$\square$
$\square$
$\square$
$\frac{1}{4}$
$\square$
$\square$
$\square$
$\square$
$\square$

\begin{tabular}{l}
0 \\
0 \\
0 \\
0 \\
0 \\
11 \\
\hline 1
\end{tabular}

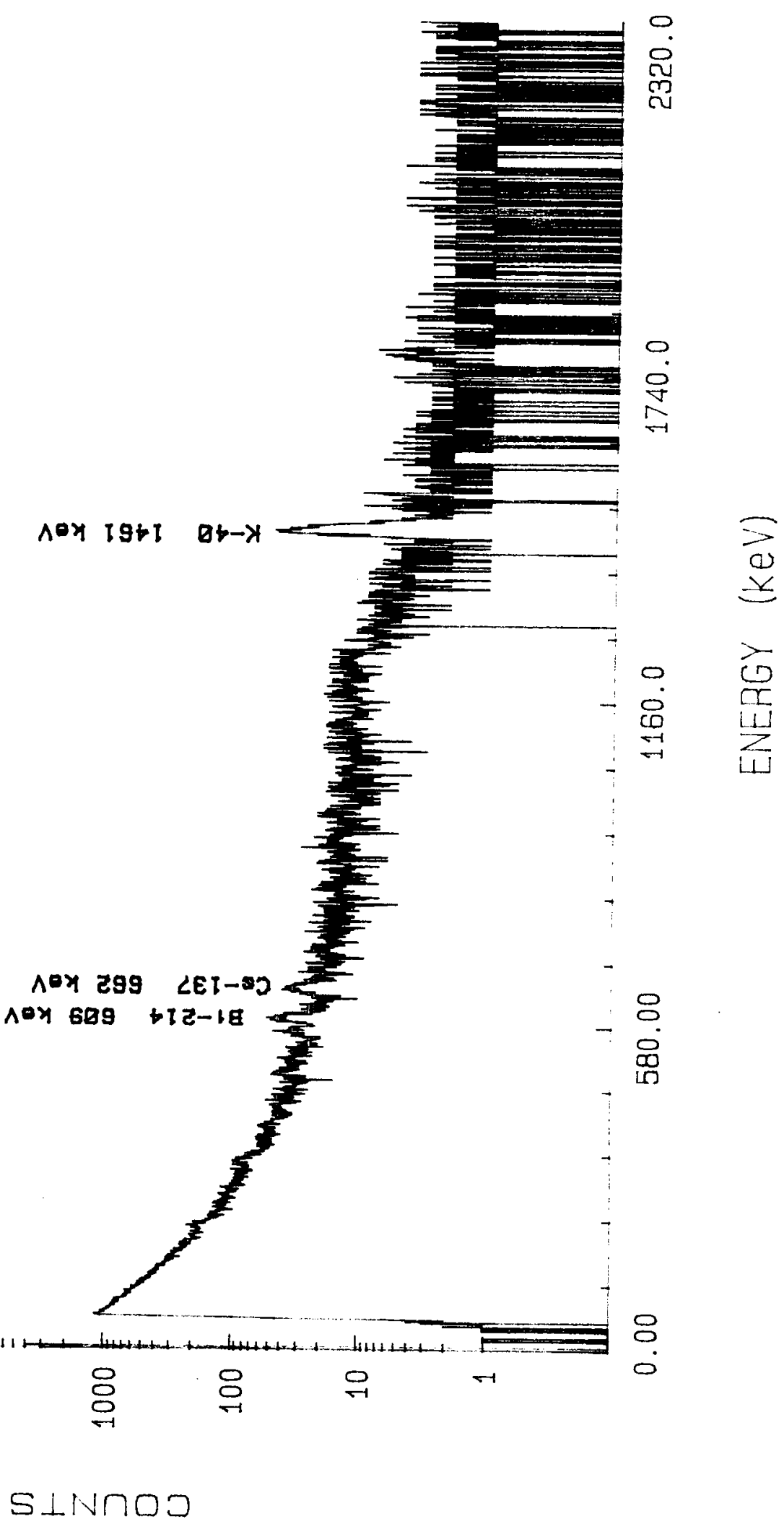




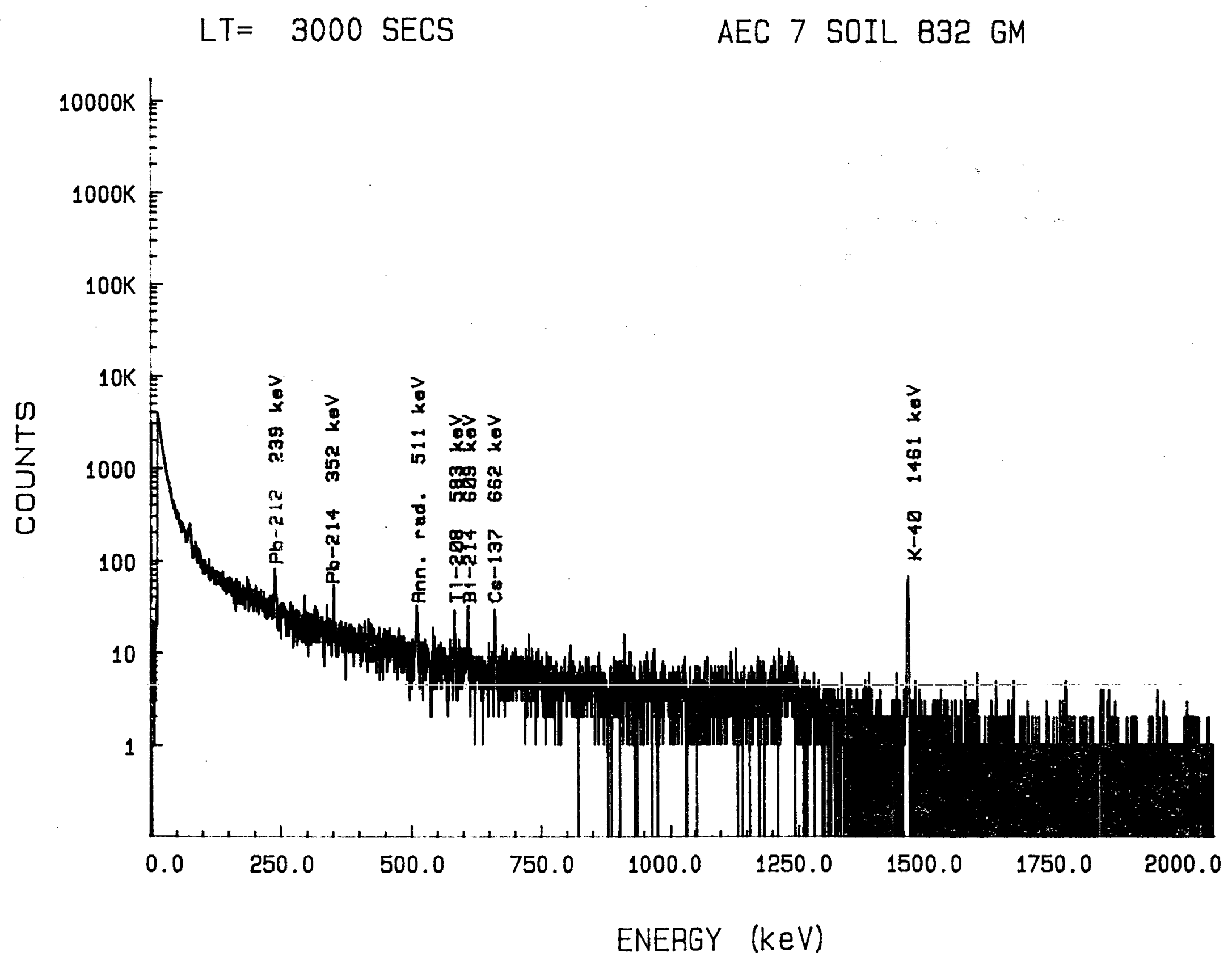




\section{$L T=2500 \mathrm{SECS}$}

\section{AEC 7 RAD. FIELD}

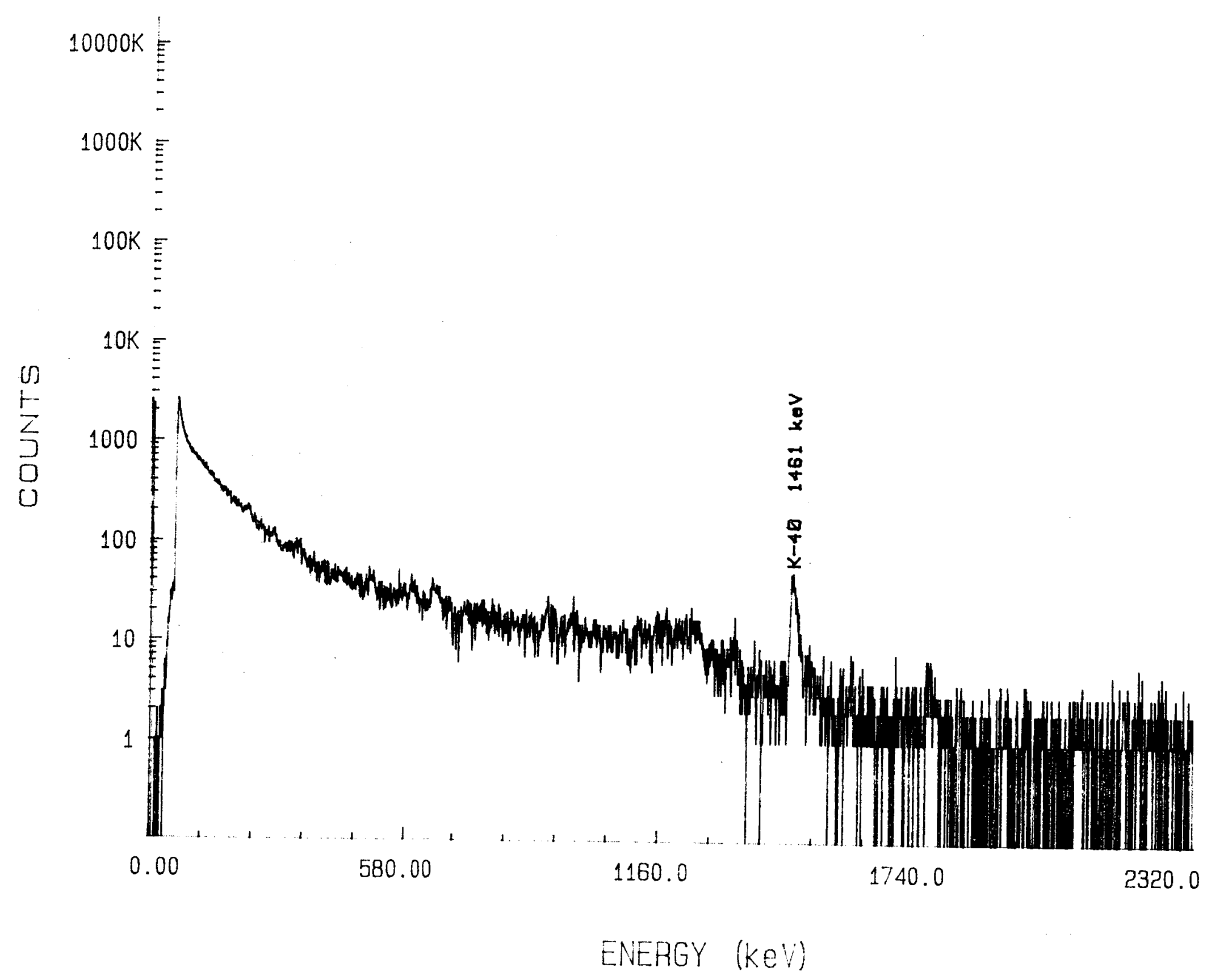



$L T=3000$ SECS
ERDA 6 SOIL 855 GM

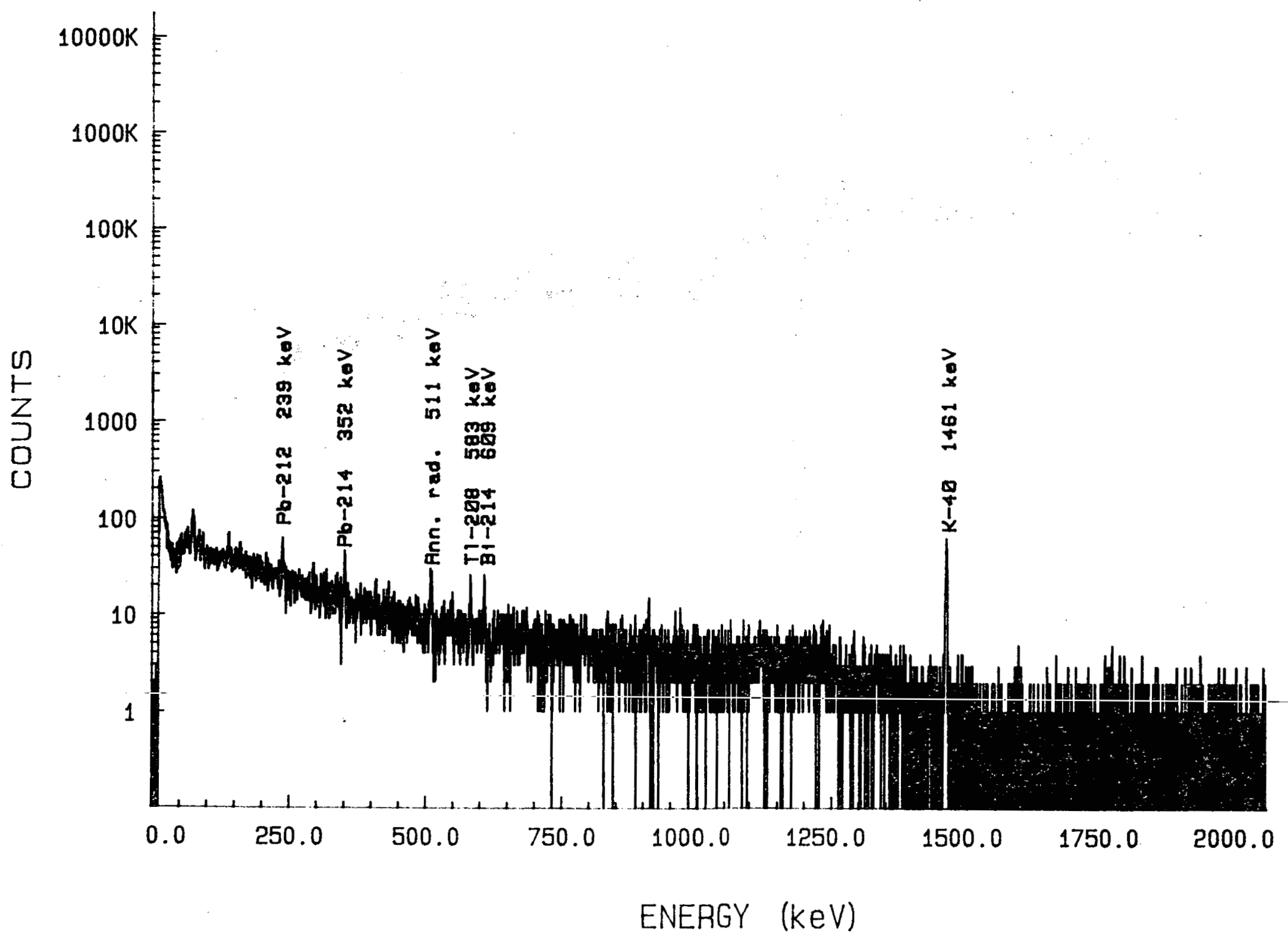




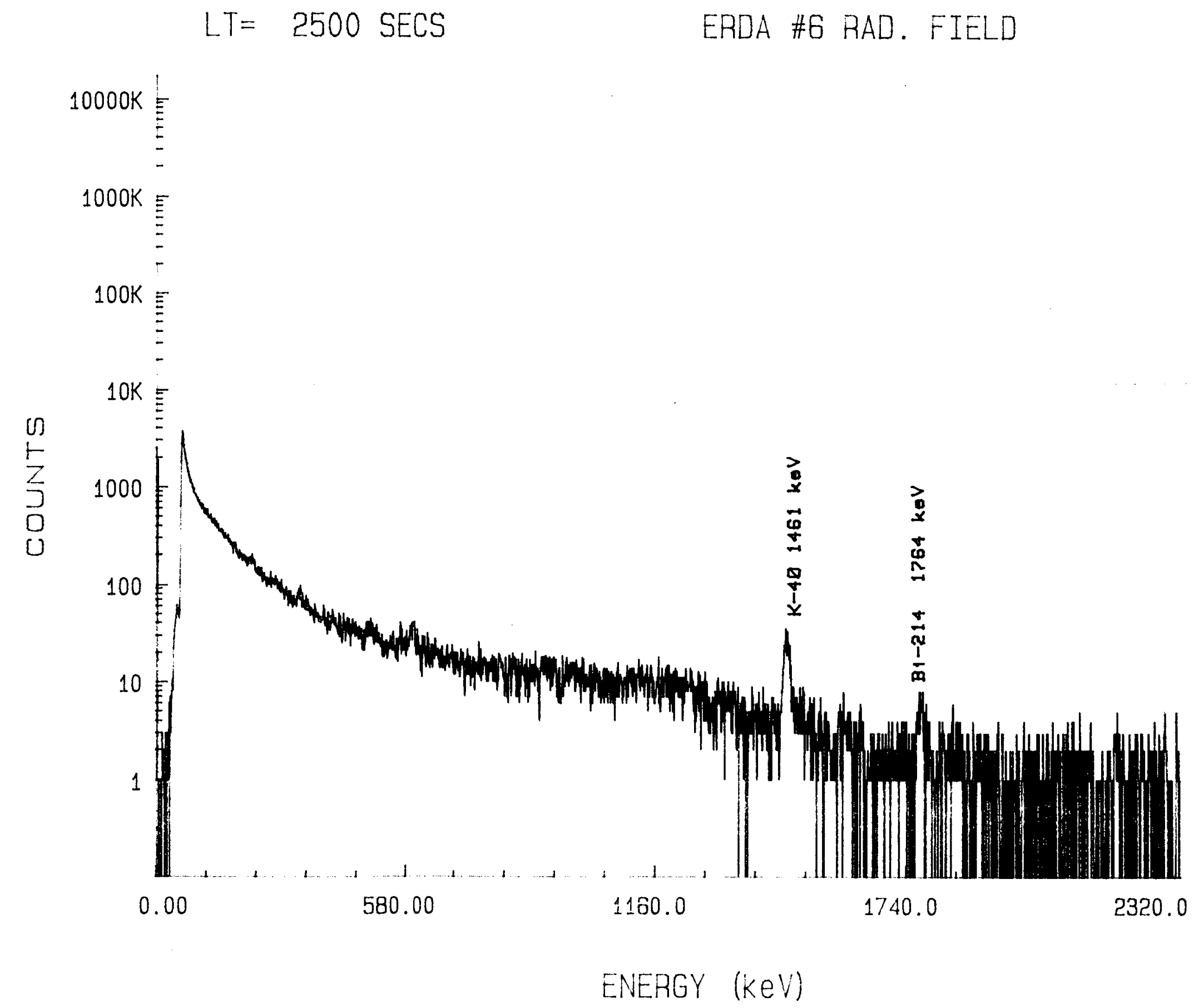


$\underset{\infty}{\omega}$

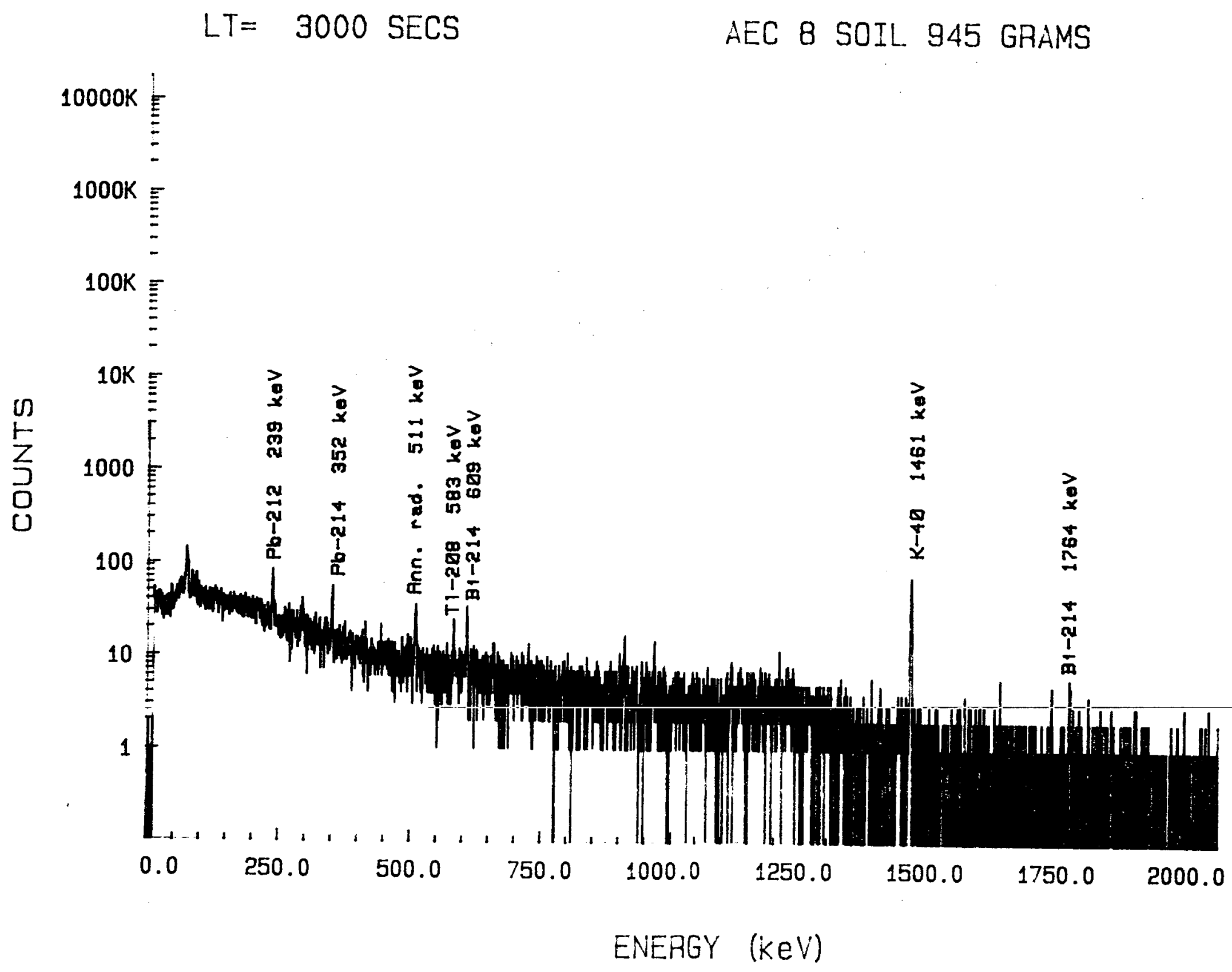




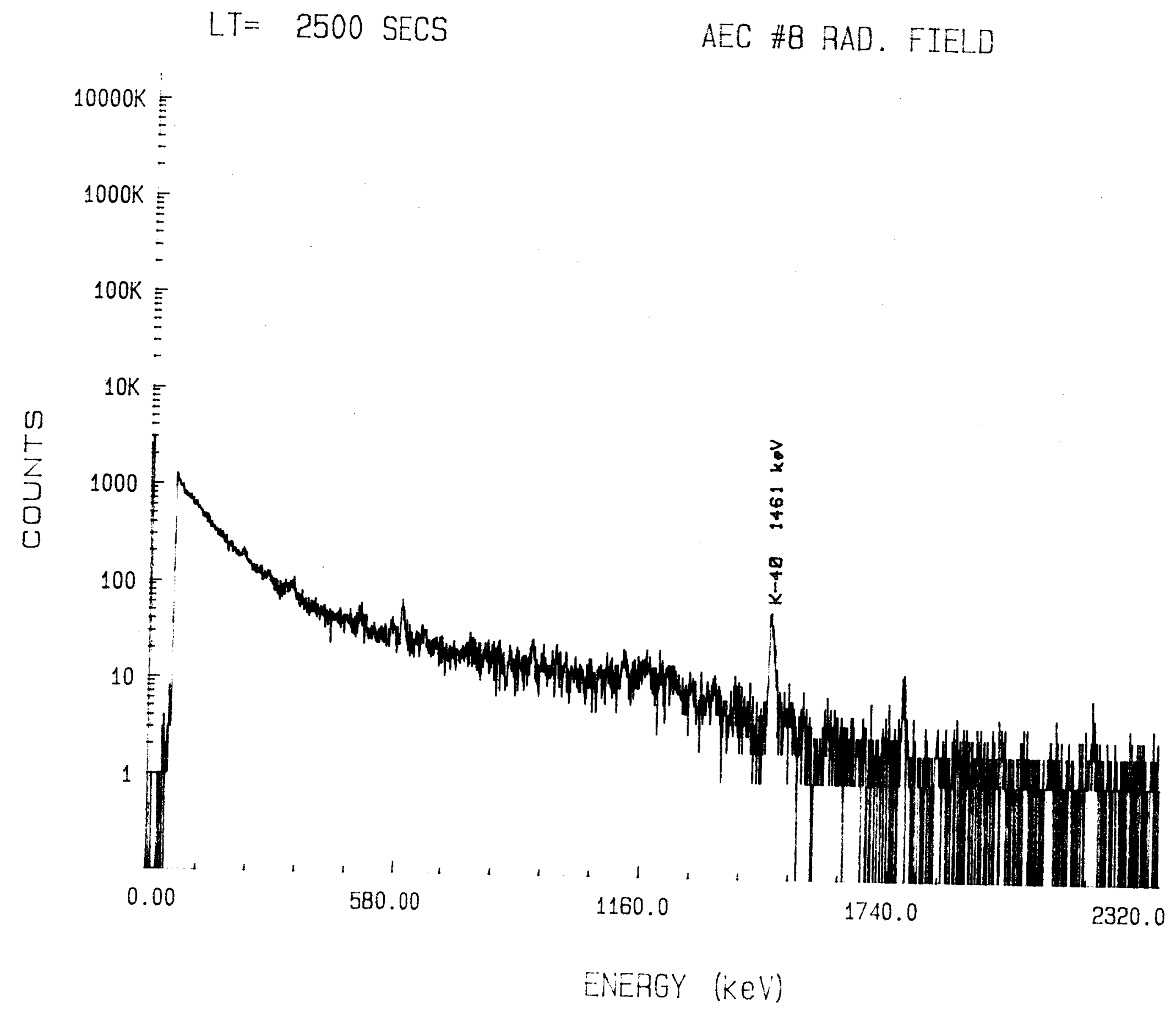




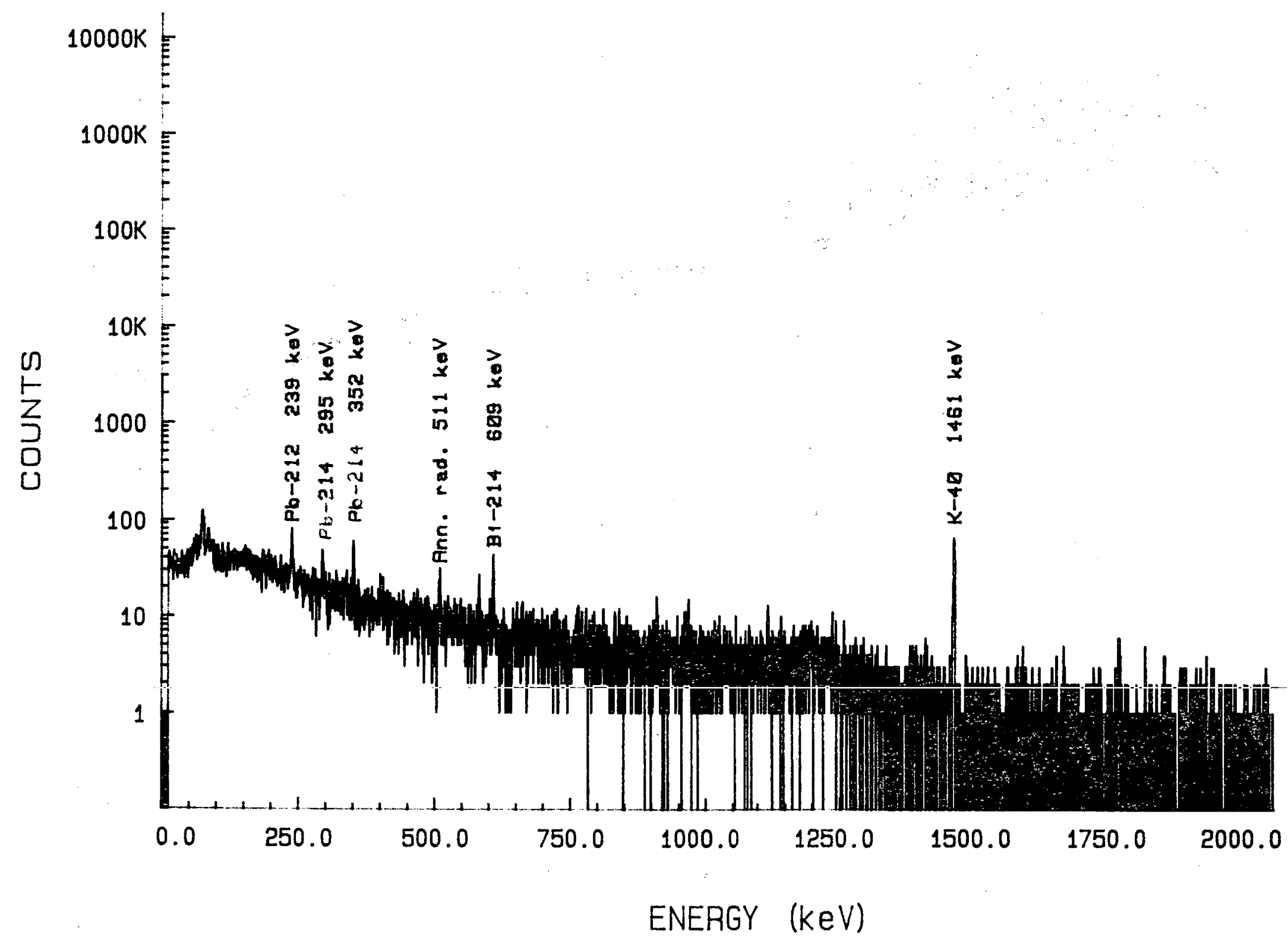



$L T=3000$ SECS
MINE OUTLET FIELD

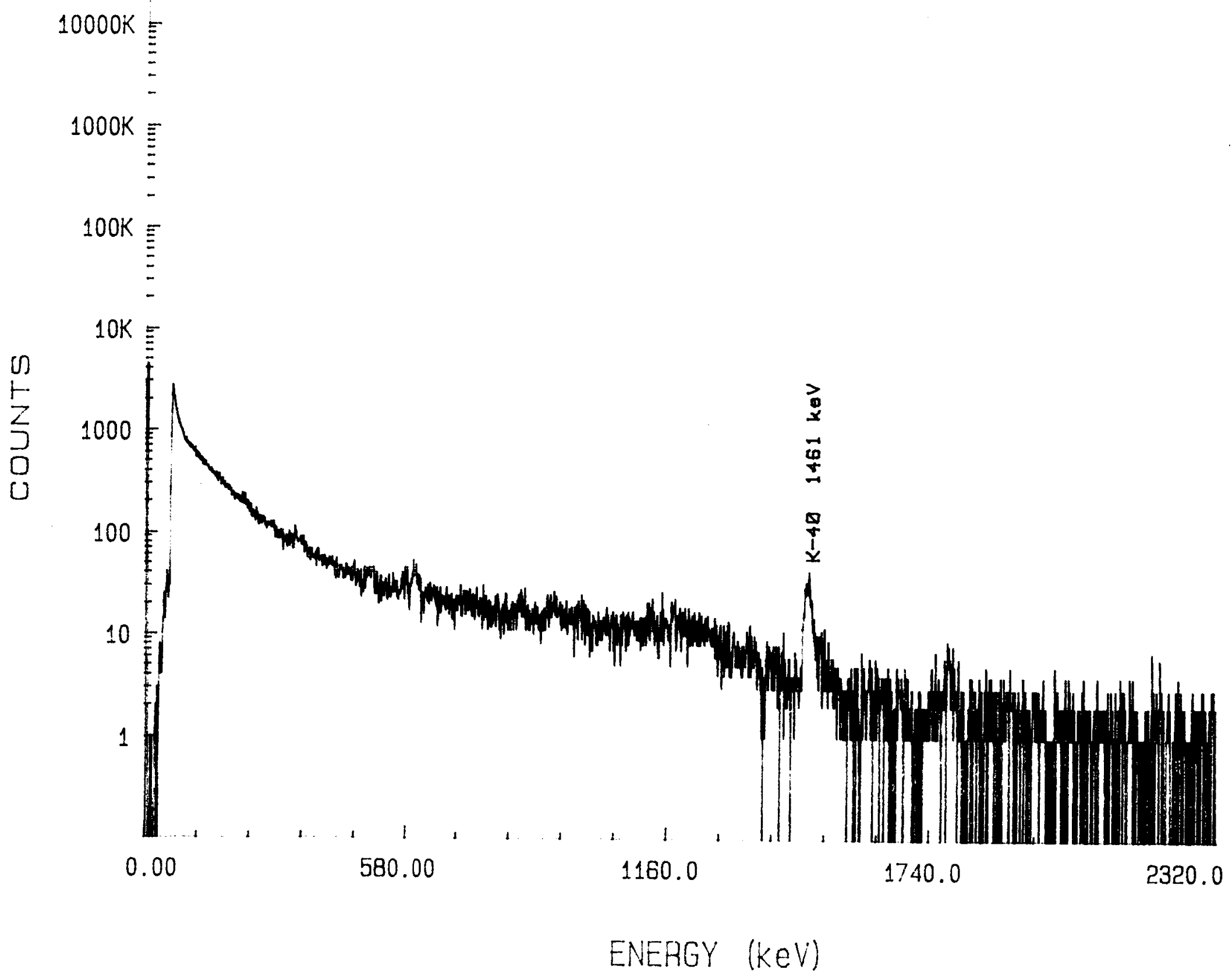


$L T=3000$ SECS WIPP E140/S3650 8356

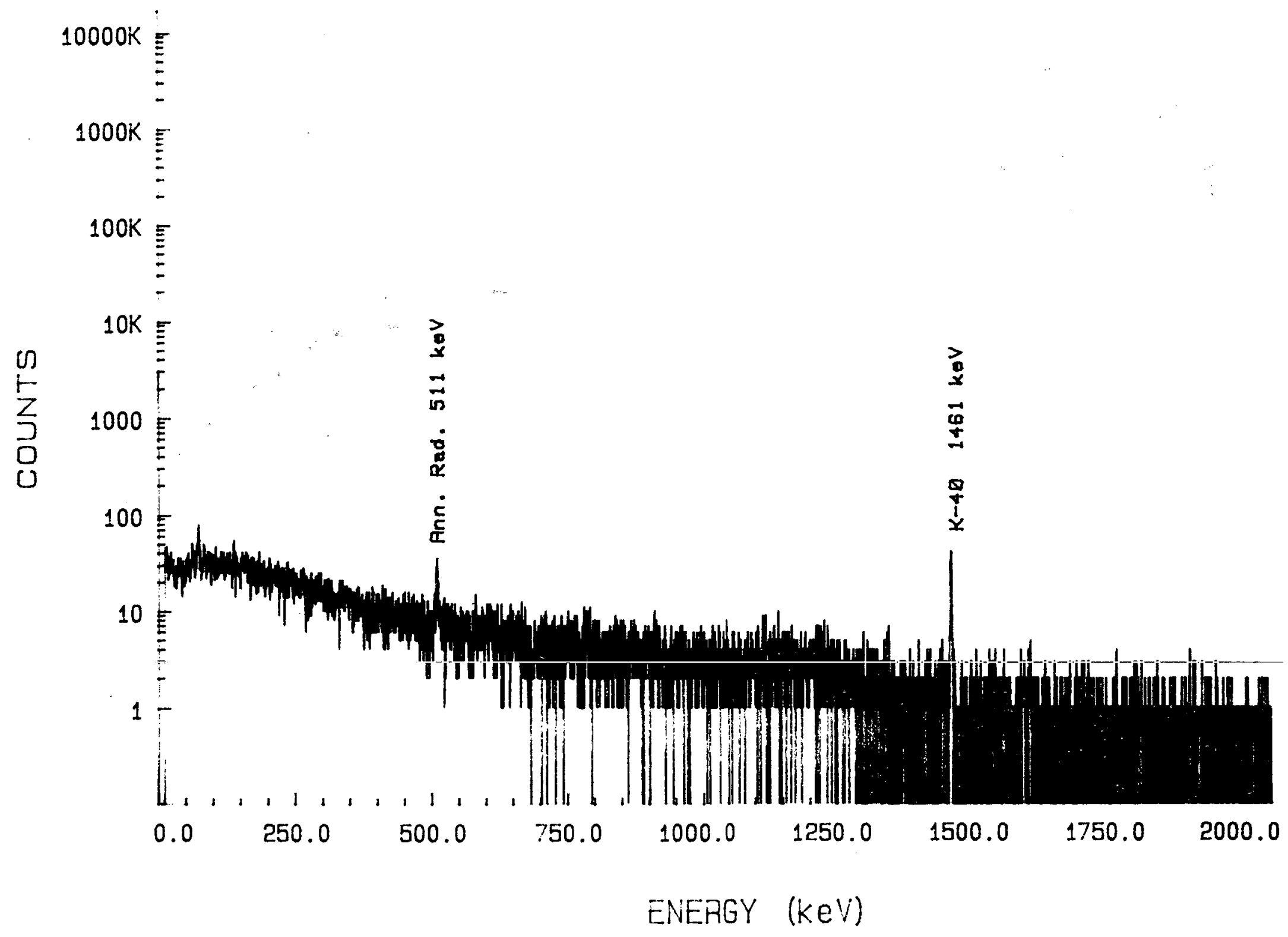


$L T=3000$ SECS

S3650'E140' RAD.FIEL

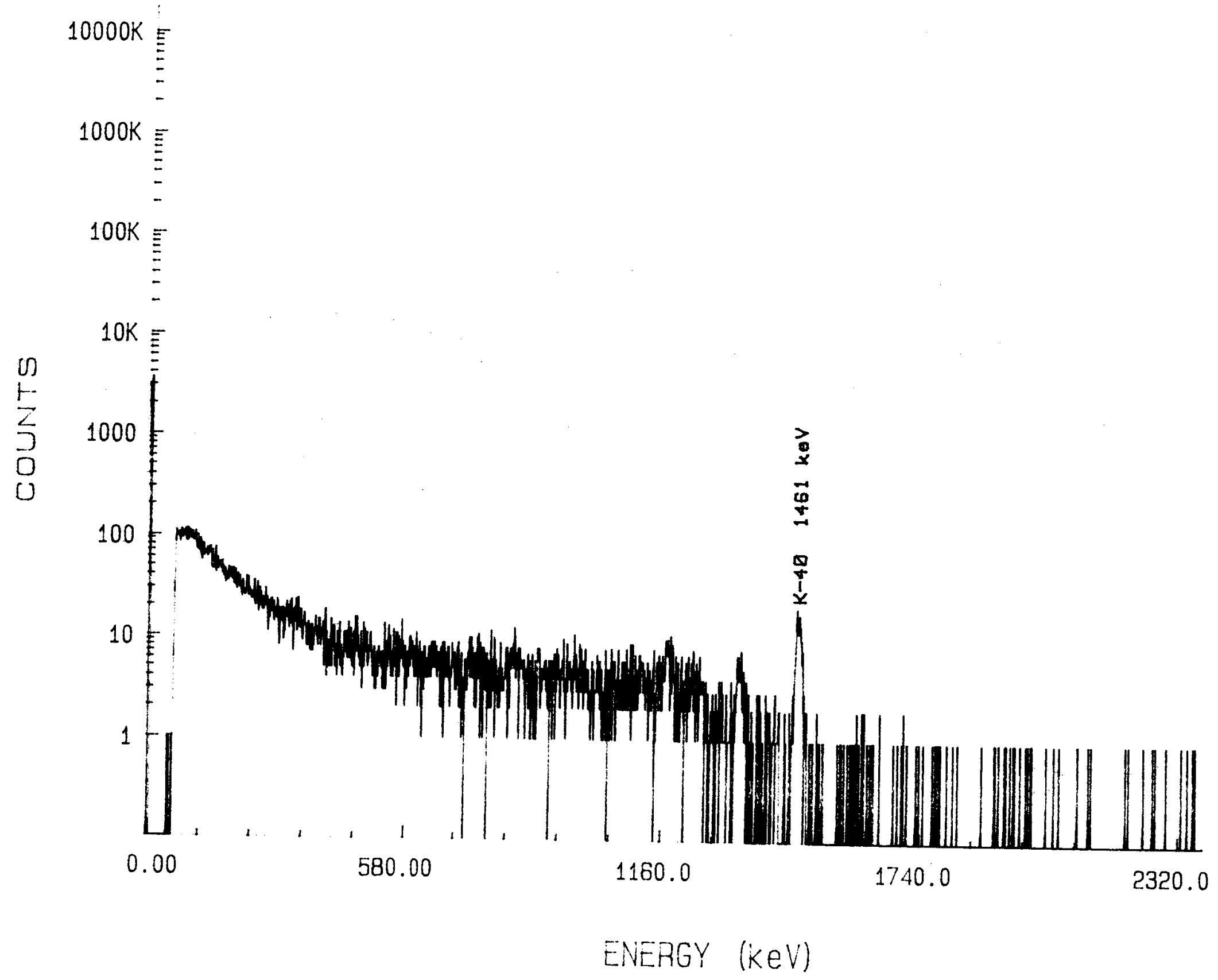




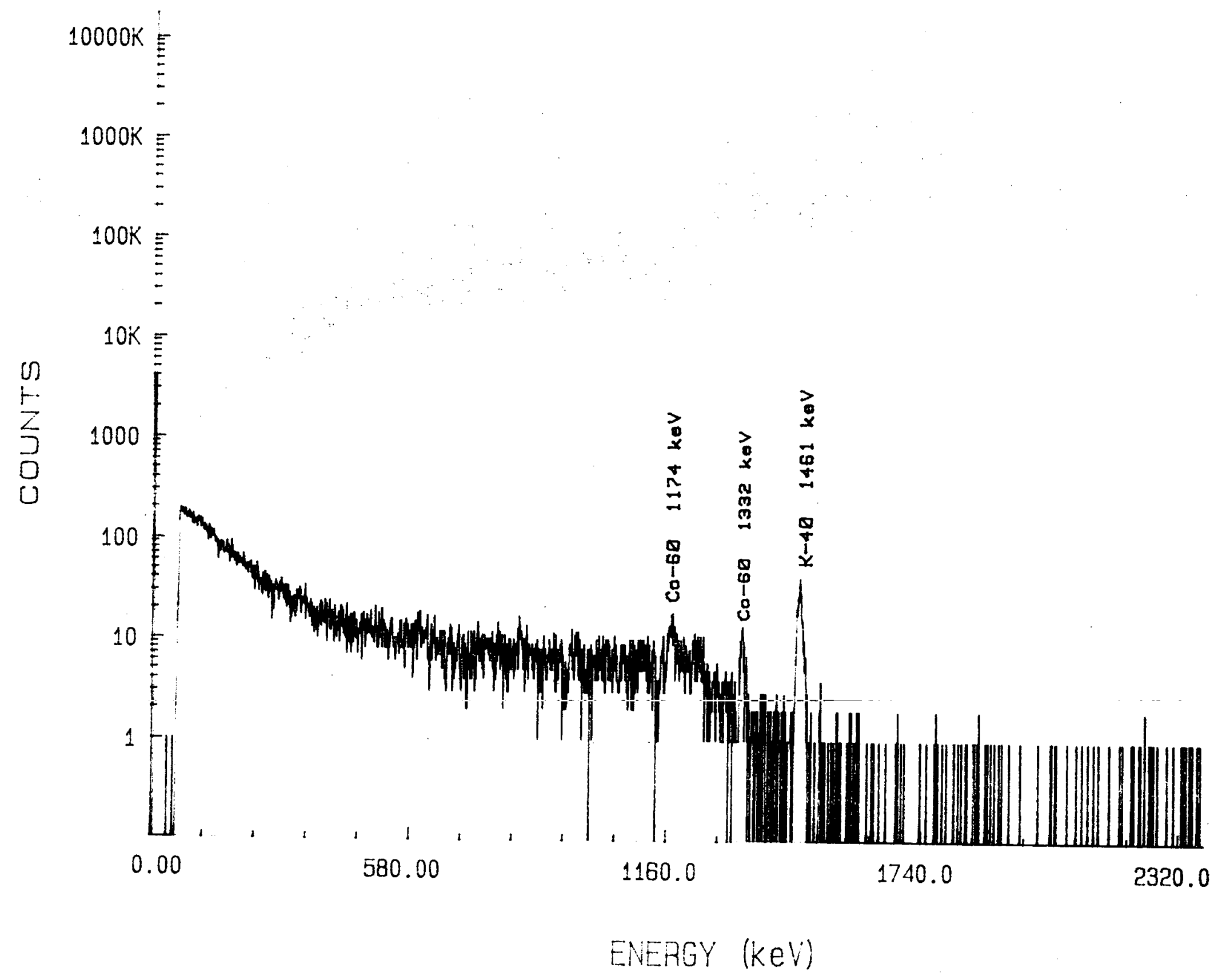




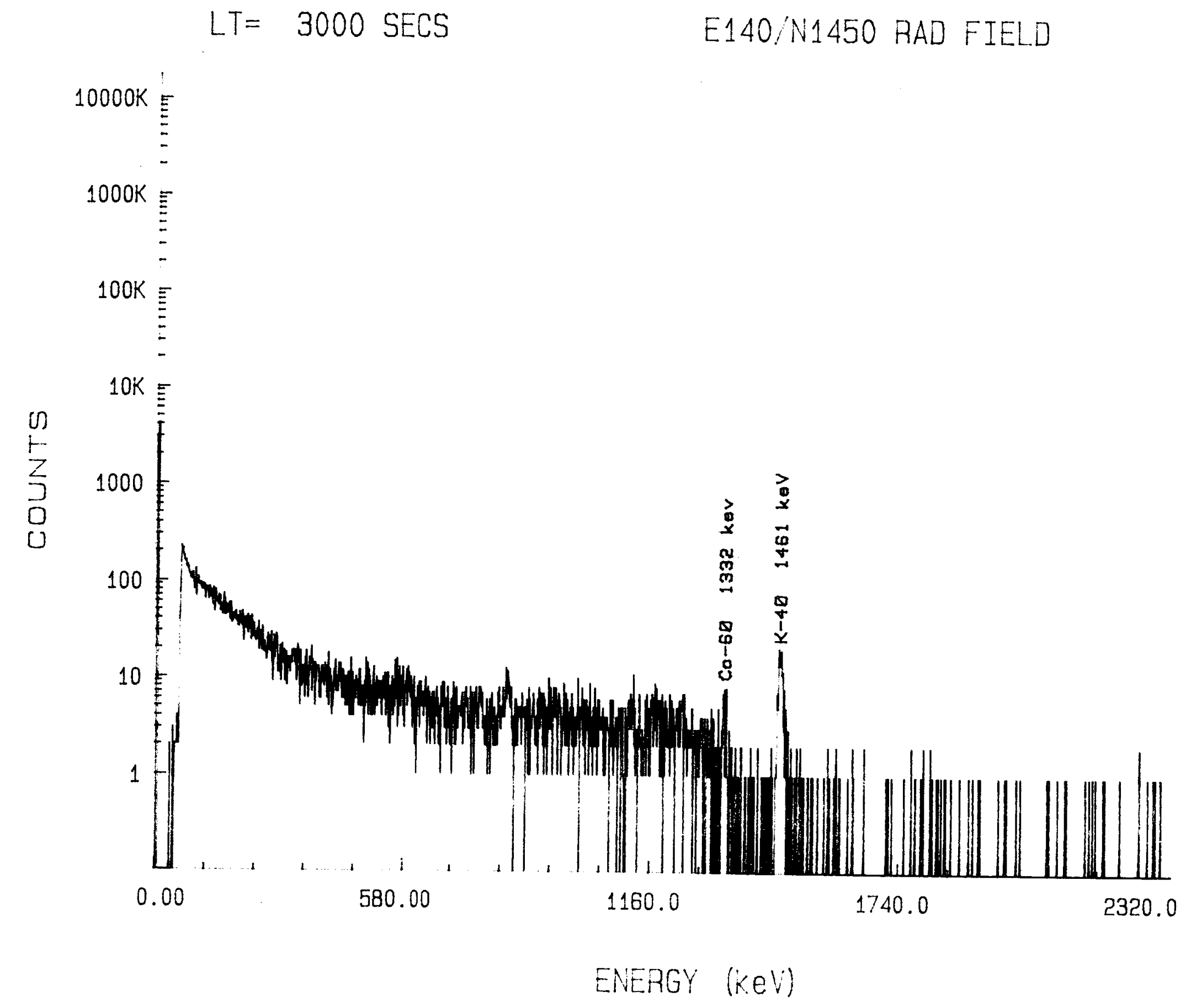



$L T=3000$ SECS
WIPP E140/N780 $880 \mathrm{G}$

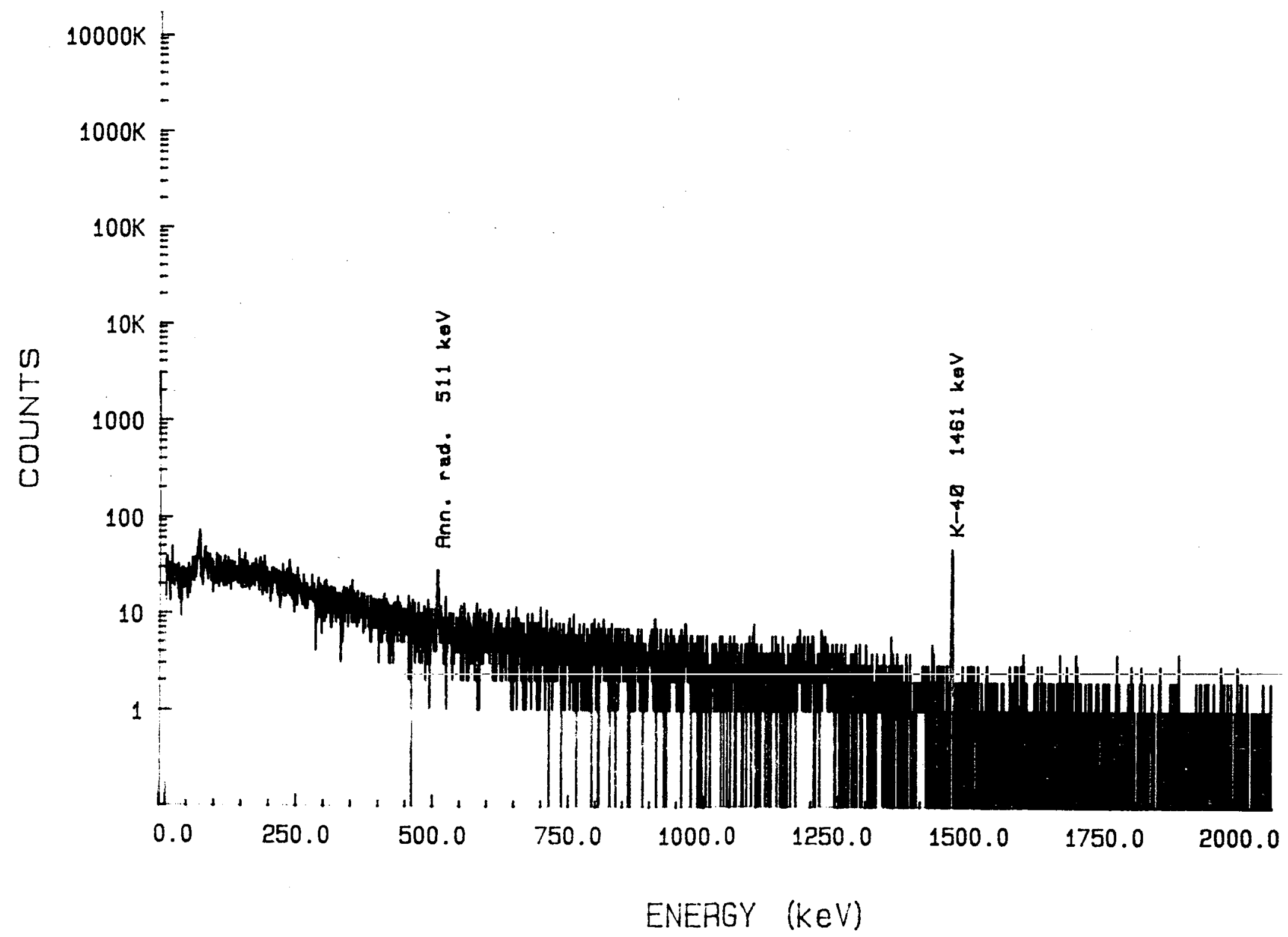



$L T=3000$ SECS
E140/N780 RAD FIELD

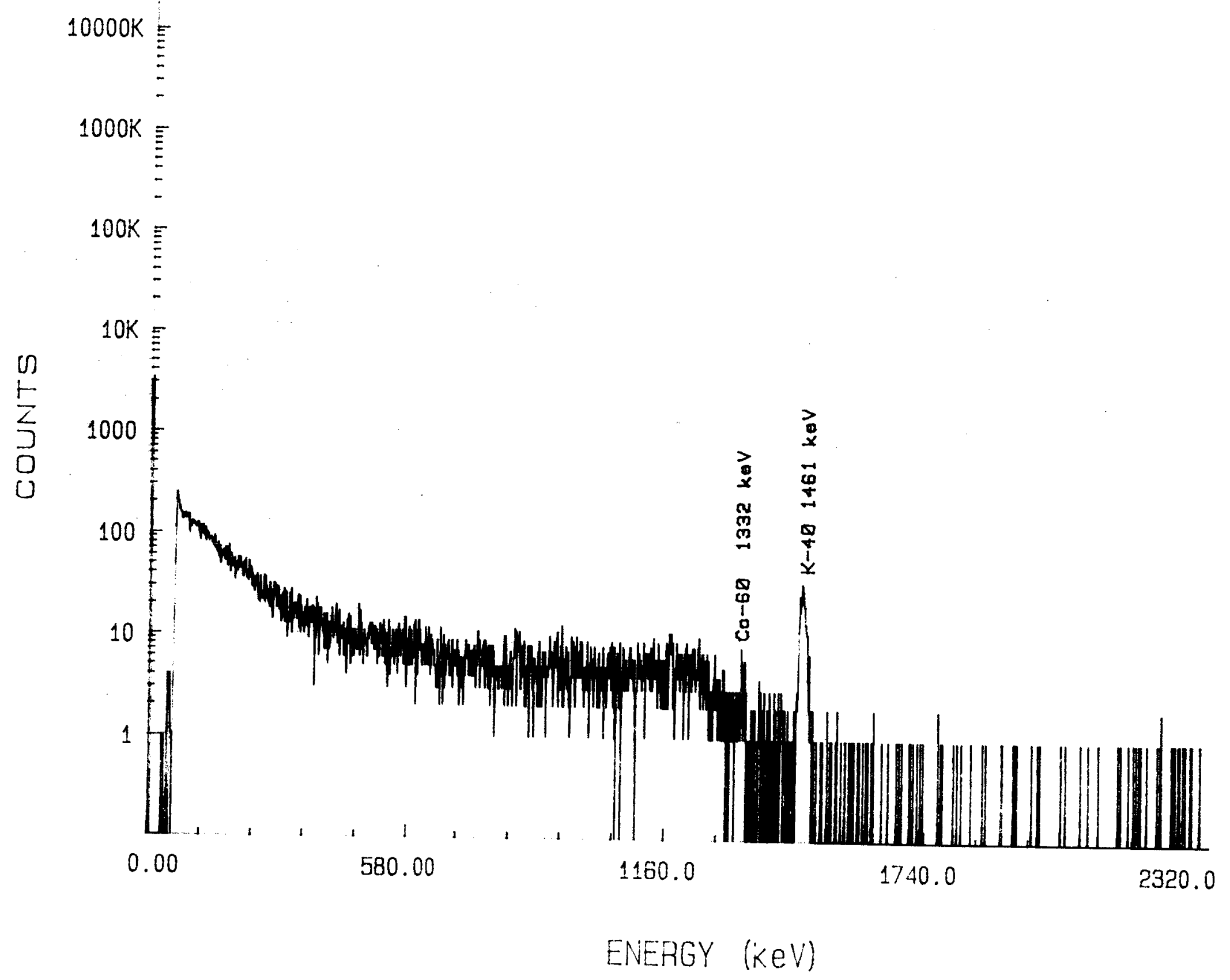




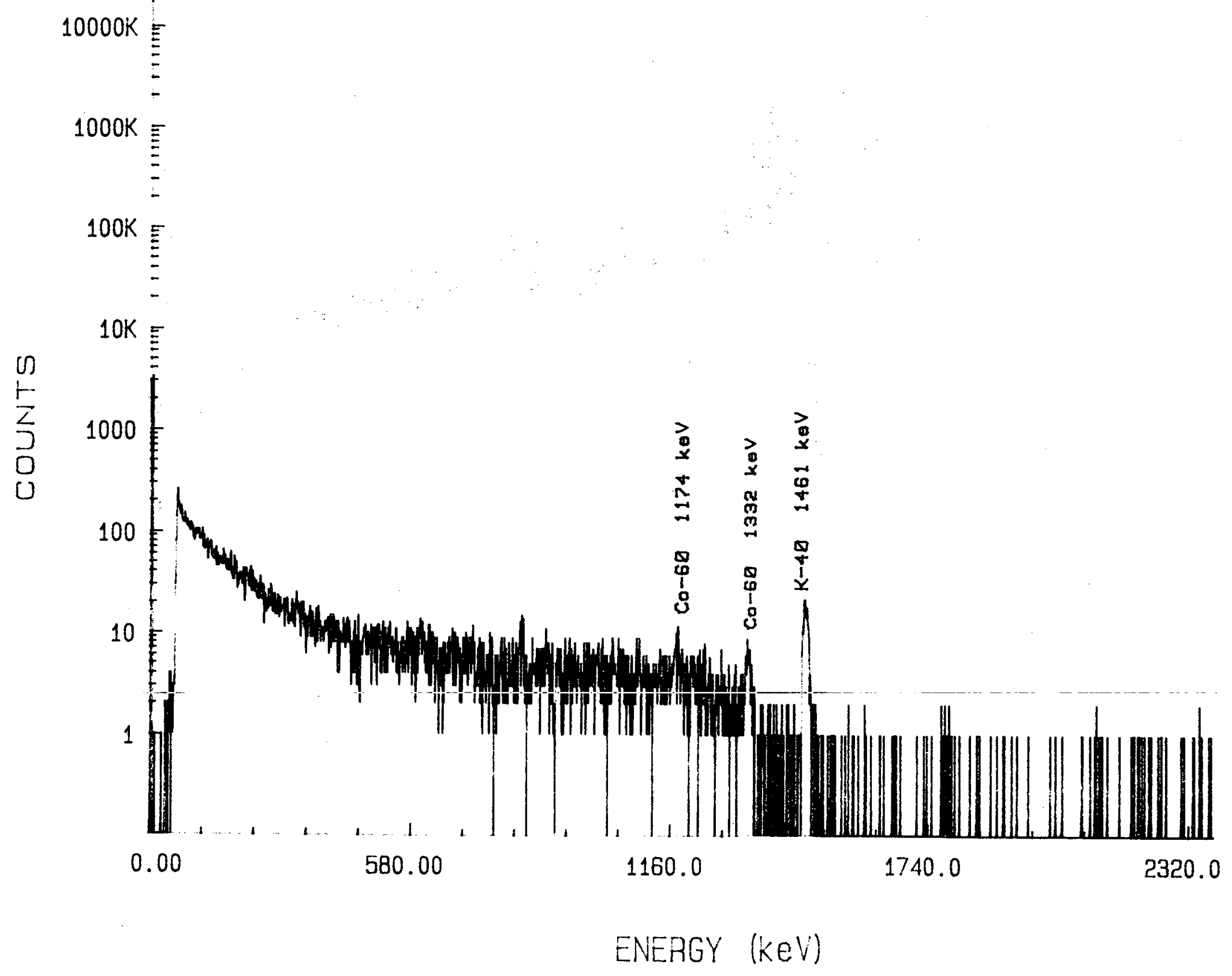




\section{DISTR I BUT ION:}

U.S. Department of Energy, Headquarters Office of Nuclear Waste Management Washington, DC 20545

Bill Bennett, Director

Divimion of Wasta Isolation (2)

U.S. Department of Energy, Headquarters Office of Defence Waste \& By-Product Washington, DC 20545

Dr. Goetz Dertel, Director (NE-320)

Larry Harmon, Frogram Manager (WIPP)

U. G. Department of Energy, Albuquerque Dperations P.Q. Box 5400

Albuquerque, NM 87185

R. Romatowski (Attn: D. Schueler)

J.M. McGough, Manager, WIPP Project Office (2)

D. Jackson, Director, Public Aftairs Division

W. Jebb, Site Manager, Carl mbad

DOE WIPP Project office

F. Q. Box 2078

Carlsbad, NM 88221

U.S. Department of Energy

c/o Battelle Office of Nuclear Waste Isolation

sos king Avenue

Col umbus, OH 43201

Jeff 0 . Neff

Battelle Memorial Institute

office of Nuclear Waste Imolation

505 King Avenue

Columbus, ㅁH 43201

5. Goldsmith, Manager (3)

DNWI Library

Battel le Memorial Institute

Project Management Division

5os king Avenue

Columbus, OH 43201

Neal Carter, General Manager

Bechtel National, Inc.

Fifty Beale Street.

P. Q. Box 3965

San Francisco, CA 94119

Edward Weber, Jr.

Dale Roberts 


\section{DISTRIEUTION (cont):}

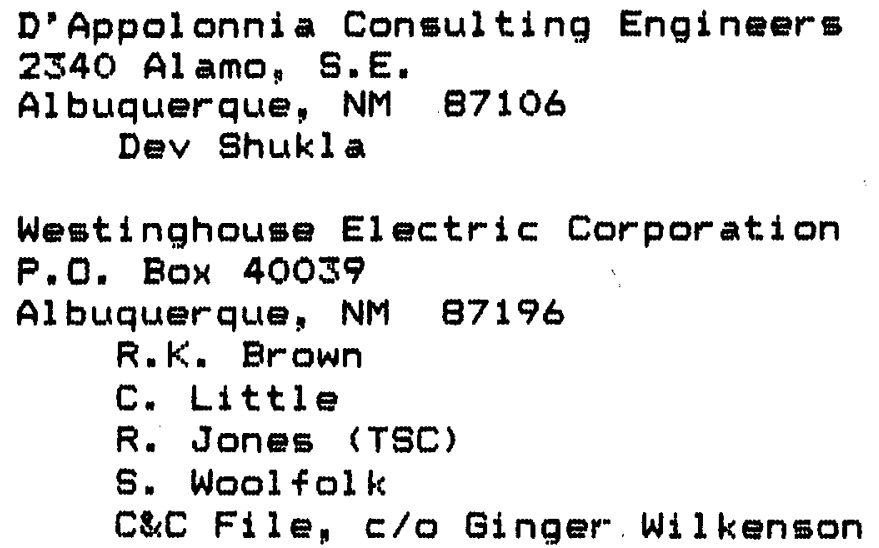

National Academy of Sclencas, WIPF Panel

Frank L. Parker, Chairman

Department of Environmental and Water Resources Engineering

Vanderbilt University

Nashvilie, TN 37235

Konrad B. Krauskopf, Chairman

Department of Geology

Stanford Univermity

Stanford, CA 94305

Karl P. Cohen, Member

Consul tant

$928 \mathrm{~N}$. California Avenue

Palo Alto, CA 94303

Neville G. Cook, Member

Dept. of Materi 1 Sciences and Engineering

University of California at Berkeley

Hearst Mining Building \$320

Berkeley: CA 94720

Fred M. Ernsberger, Member 250 old Mill Road

Pittsburgh, PA 15238

Richard R. Parizek, Member

Department of Hydrogeology

Pennsylvania State University

Univermity Park, PA 16802

D'Arcy A. Shock, Member

233 Virginia

Ponce City, OK 74601

John W. Winchester, Member

Department of Dceanography

Florida state University

Tallahassee, FL 32306 
John T. Holloway

Senior Staff officer

2101 Constitution Avenue, NW

Washington, DC 20418

WIPP Public Reading Room

Atomic Museum, Kirtland East AFB

Albuquerque, NM 87185

Attn: Ms. Gwynn Bchreiner

WIPP Public Reading Room

Carl mbad Munieipal Library

101 S. Hall agueno St.

Carlsbad, NM B8220

Attn: Lee Hubbard, Head Librarian

Thomas Brannigan Library

106 W. Hadley St.

Las Cruces, NM 88001

Attn: Don Dresp, Head Librarian

Roswel 1 Public Library

301 N. Pennsylvania Avenue

Roswe11, NM 88201

Attn: Ms. Nancy Langston

Hobbs Public Library

Sog N. Ship St.

Hobbs: NM 88248

Ms. Marcia Lewis, Librarian

State of New Mexico

Environmental Evaluation Group

320 Marcy Street

P.D. BOX 968

Santa Fe, NM 87503

Robert H. Neili, Director (2)

NM Department of Energy \& Mineral w

P.D. Bax 2770

Santa Fe, NM 87501

P. Biderman, Secretary

kasey LaPlante, Librarian

Dr. Ed Kelley, Director

Mining \& Mineral Division

525 Camino de los Marquez

Santa Fe, NM 87501

New Mexico State Library

P.0. Box 1629

Santa Fe, NM 8750S

Ms. Ingrid Volienhofer 


\section{DISTRIBUTION (cont):}

New Mexico Tech

Martin Speer Memorial Library

Campus Street

Socorro, NM 87801

Reference Department

Zimmerman Library

University of New Mexico

Albuquerque, NM 87131

Ms. Zanier Vivian

USGS, Water Resources Division

505 Marquette, NW

Western Bank Building., \#720

Albuquerque, NM 87102

J.W. Mercer (2)

USGS, Special Projects Branch

Federal Center, Bldg. 25

Denver, Co 80225

R.P. Snyder (2)

New Mexico Bureau of Mines and Mineral Resources

Socorro, NM 87801

F.E. Kattlowski, Director

U.5. Nuclear Regul atory Commission (3)

Division of Waste Management.

Mail Stop 69755

Washington, DC 20555

Attn: M. Bell

USGS, Conservation Division

P.O. Box 1857

Roswe11. NM 88201

W. Melton

Gayle Pawloski, L-222

Geologist CSDP

Lawrence Livermore Laboratory

Livermore, CA 94550

Dr. Gary L. Downey

Center for Waste Management Programs

Department of Social Sciences

Michigan Technological Univermity

Houghton, MI 49931 


\section{DISTRIBUTION (cont):}

Kil aus kiuhn

Gesel lschaft fuer Strahlen-und

Umwel tforschung MBH Muenchen

Inotitut fuer Tiefl agerung

Berliner Strasse 2

3392 Clausthal-Zel lerfeld

Federal Republic of Germany

K1 aus Eckart Mams

Hahn-Meitner-Institut fuer Kernforrschung

GIienicker Strasse 100

1000 Berlin 39

Federal Republic of Germany

Michael Langer

Bundesanstalt fuer beowissenschften und Rohstoffe

Postfach 510153

3000 Hannover 51

Federal Republic of Germany

Hel mut Rothemeyer

Physikal isch-Technische

Bundesanstalt

Bundesalle 100

3300 Braunschweig

Federal Republic of Germany

Rolf-Peter Randl.

Bundesministerium fuer forschung und Technologie

Postfach 200706

5300 Bonn 2

Federal Republic of Germany

Sandia Internal:

3141 L.J. Erickson (5)

3151 W.L. Gamer, For: DOE/TIC (Unlimited Feleame) (3)

3154-3 C.H. Dalin, Far: DOE/TIC (25)

3300 P.B. Mossman, MD

3310 W.D. Burnett

3312 G.E. Tucker, Jr.

3312 D.M. Minnema (20)

6300 R.W. Lynch

6330 W.D. Weart

6331 A.R. Lappin

6.332 T.Q. Hunter

6.332 Sandia WIPP Central Files (2) (Code: WEE)

6332 R.V. Matalueci

8214 M.A. Pound 